\title{
Measure Guideline: Ventilation Guidance for Residential High- Performance New Construction - Multifamily
}

Joseph Lstiburek Building Science Corporation
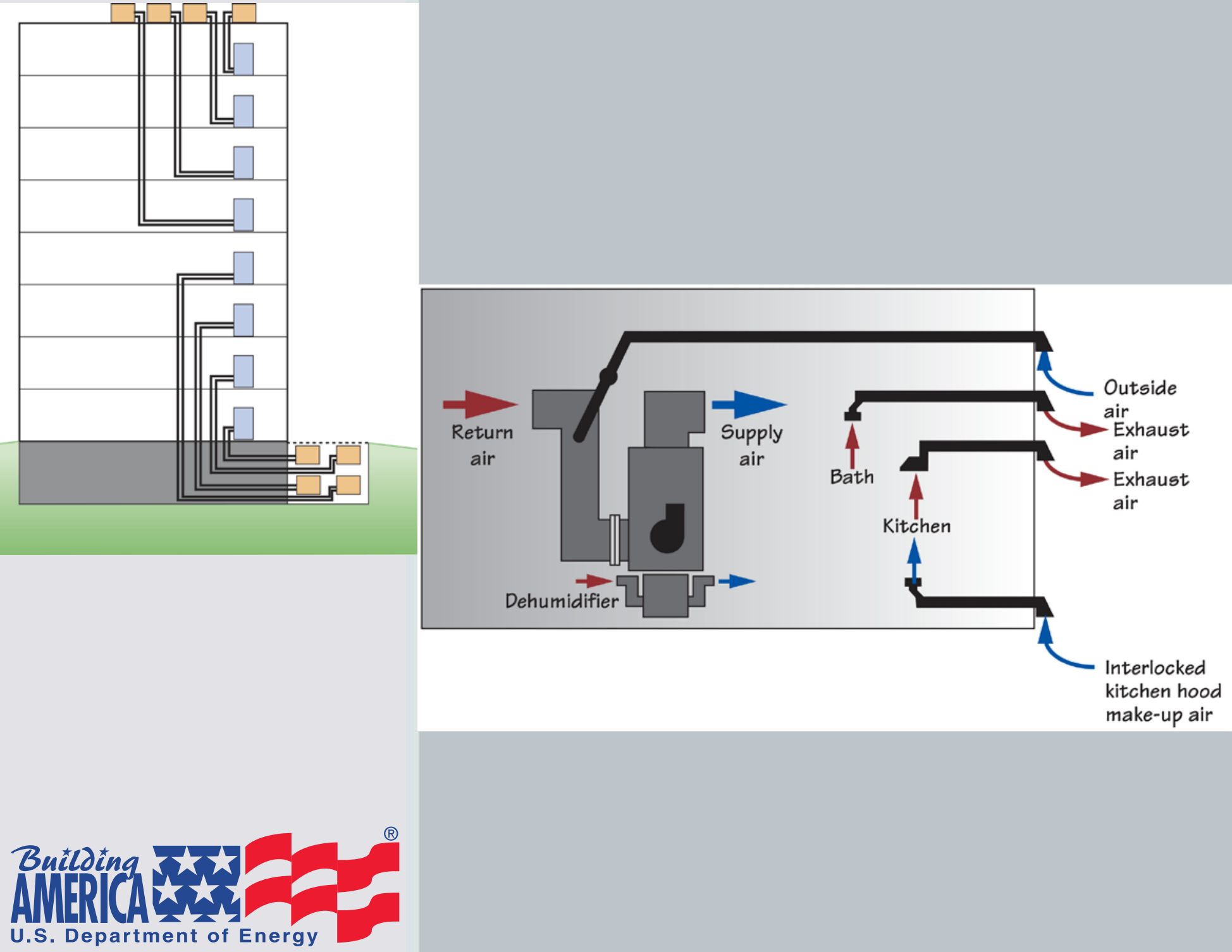


\section{NOTICE}

This report was prepared as an account of work sponsored by an agency of the United States government. Neither the United States government nor any agency thereof, nor any of their employees, subcontractors, or affiliated partners makes any warranty, express or implied, or assumes any legal liability or responsibility for the accuracy, completeness, or usefulness of any information, apparatus, product, or process disclosed, or represents that its use would not infringe privately owned rights. Reference herein to any specific commercial product, process, or service by trade name, trademark, manufacturer, or otherwise does not necessarily constitute or imply its endorsement, recommendation, or favoring by the United States government or any agency thereof. The views and opinions of authors expressed herein do not necessarily state or reflect those of the United States government or any agency thereof.

This report is available at no cost from the National Renewable Energy Laboratory (NREL) at www.nrel.gov/publications.

Available electronically at SciTech Connect http:/www.osti.gov/scitech

Available for a processing fee to U.S. Department of Energy and its contractors, in paper, from:

U.S. Department of Energy

Office of Scientific and Technical Information

P.O. Box 62

Oak Ridge, TN 37831-0062

OSTI http://www.osti.gov

Phone: 865.576.8401

Fax: 865.576.5728

Email: reports@osti.gov

Available for sale to the public, in paper, from:

U.S. Department of Commerce

National Technical Information Service

5301 Shawnee Road

Alexandria, VA 22312

NTIS http://www.ntis.gov

Phone: 800.553 .6847 or 703.605 .6000

Fax: 703.605.6900

Email: orders@ntis.gov 


\title{
Measure Guideline: Ventilation Guidance for Residential High-Performance New Construction - Multifamily
}

\author{
Prepared for: \\ The National Renewable Energy Laboratory \\ On behalf of the U.S. Department of Energy's Building America Program \\ Office of Energy Efficiency and Renewable Energy \\ 15013 Denver West Parkway \\ Golden, CO 80401 \\ NREL Contract No. DE-AC36-08GO28308 \\ Prepared by: \\ Joseph Lstiburek, Ph.D., P.Eng. \\ Building Science Corporation \\ 3 Lan Drive, Suite 102 \\ Westford, MA 01886 \\ NREL Technical Monitor: Stacey Rothgeb \\ Prepared under Subcontract No. KNDJ-0-40337-05
}

January 2017 
The work presented in this report does not represent performance of any product relative to regulated minimum efficiency requirements.

The laboratory and/or field sites used for this work are not certified rating test facilities. The conditions and methods under which products were characterized for this work differ from standard rating conditions, as described.

Because the methods and conditions differ, the reported results are not comparable to rated product performance and should only be used to estimate performance under the measured conditions. 


\section{Contents}

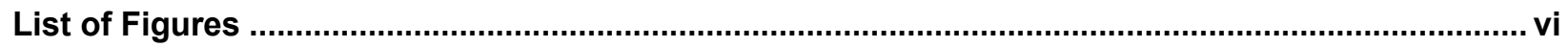

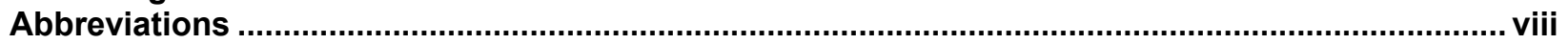

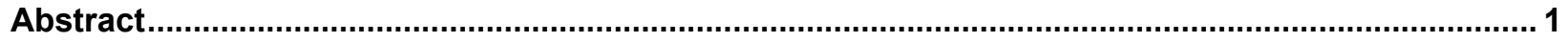

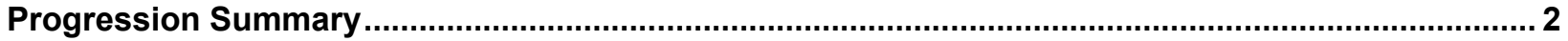

1 Introduction

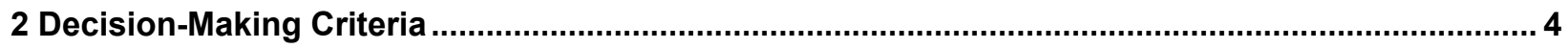

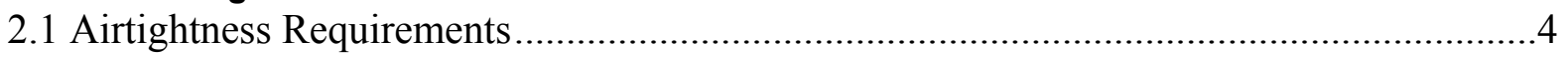

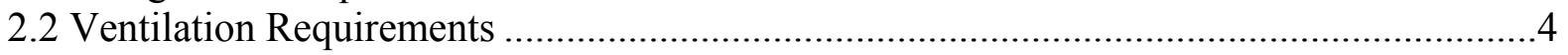

2.3 Implications for Multifamily Ventilation Design ..................................................

2.4 System Selection: Advantages, Disadvantages, and Costs .........................................6

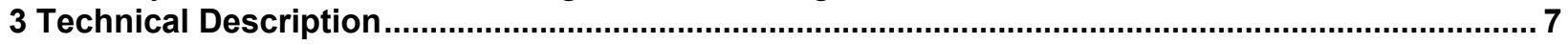

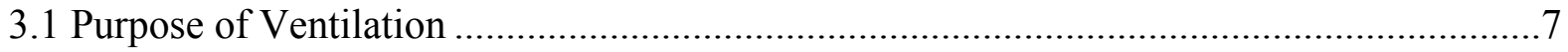

3.2 Uniqueness of Multifamily Construction............................................................ 7

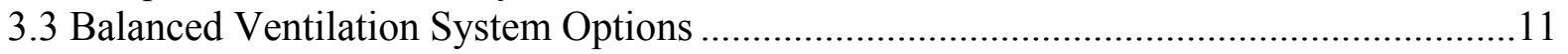

3.4 Corridors, Elevator Shafts, and Trash Chutes...................................................... 18

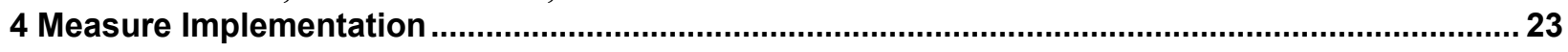

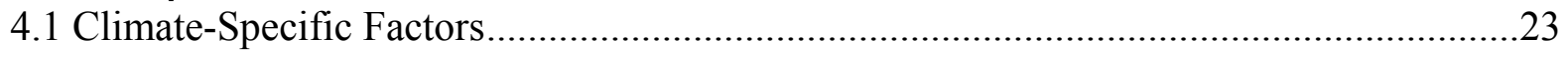

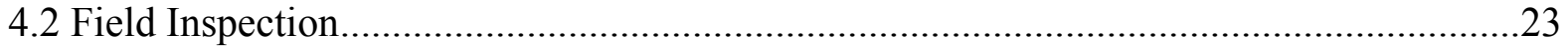

System 1: Forced Air - Outside Air to Return Side of Air Handler......................................24

System 2: Forced Air-Outside Air to Return Side of Air Handler, Supplemental

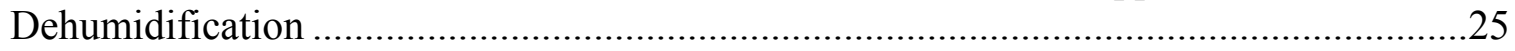

System 3: Forced Air-Heat Recovery Ventilator/Energy Recovery Ventilator...................26

System 4: Forced Air-Heat Recovery Ventilator/Energy Recovery Ventilator, Supplemental

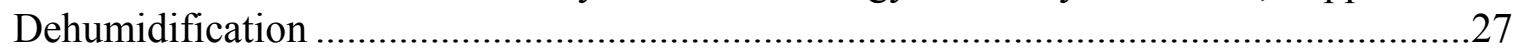

System 5: Packaged Terminal Heat Pump_Heat Recovery Ventilator/Energy Recovery

Ventilator ......................................................................................................28

System 6: Packaged Terminal Heat Pump-Heat Recovery Ventilator/Energy Recovery

Ventilator, Supplemental Dehumidification .................................................................29

System 7: Radiant Heating-Heat Recovery Ventilator/Energy Recovery Ventilator ............30

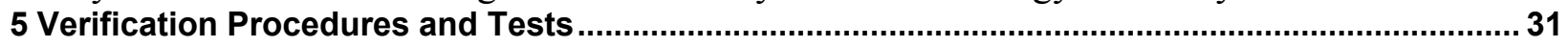

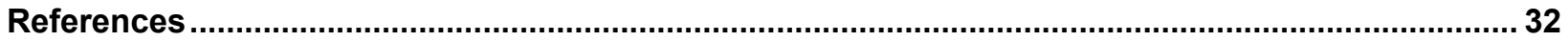




\section{List of Figures}

Figure 1. Only balanced ventilation strategies are recommended for most multifamily construction

Figure 2. Multifamily construction-Multifamily units share common surface areas with neighboring units. Ventilation air should not be pulled from neighboring units, for fire- and smoke-control, odor-control, and general IAQ reasons.

Figure 3. Common wall construction-Common walls are required to meet fire and smoke assembly requirements

Figure 4. Floor assembly air sealing-Floor assemblies that are soundproofed and fireproofed with liquid gypsum subflooring result in airtight wall assemblies at floor to wall connections . 8

Figure 5. Weatherstripped corridor doors-Ventilation air is prohibited from being introduced into multifamily units from corridors; doors from multifamily units to corridors are typically weatherstripped.

Figure 6. Passive air inlet-Ventilation air can only be introduced into multifamily units by infiltration through exterior walls or directly into the units by ducted supply or passive air inlets (holes in the exterior walls).

Figure 7. Stack effect in a multistory building-Stack-effect-driven airflows in multistory buildings compromise smoke control and fire safety, adversely affect IAQ and comfort and increase operating costs for space conditioning energy .

Figure 8. Stack-effect-driven airflow-The air in lower units ends up in the upper units ................. 10

Figure 9. Compartmentalization-Basically, you turn a 10-story building into 10 one-story buildings that are stacked on top of one another; by isolating the units from each other and from corridors, shafts, elevators, and stairwells, stack-effect-driven interior airflows can be controlled

Figure 10. Distributed heating and cooling systems-Each unit is conditioned individually ........... 12

Figure 11. Distributed heating and cooling systems-Each unit is conditioned individually .......... 12

Figure 12. Individual supply and exhaust openings-Multiple exhaust grilles and supply grilles are required

Figure 13. Individual unit space conditioning-Each unit has its own air distribution system ....... 13

Figure 14. Electric water heater-Electric water heaters do not need to be vented to the exterior, whereas gas water heaters do.

Figure 15. Gas water heater-Gas water heaters should be sealed combustion two-pipe systems vented directly to the exterior with combustion air ducted directly to the water heater............ 14

Figure 16. Clothes dryers-Where clothes dryers are installed, they should be unvented condensing units-or if vented to the exterior, a provision for powered make-up air must be made

igure 17. Kitchen range hood-It is recommended that make-up air be introduced below the cooking surface and that the range hood be wider and deeper than the cooking surface ........ 15

Figure 18. Dehumidifier-In return closet of forced-air system ........................................................ 16

Figure 19. Dehumidifier-In ducted return system ..................................................................... 16

Figure 20. Dehumidifier-Located in return closet ................................................................... 17

Figure 21. Dehumidifier-Located in closet with louvered door................................................. 17

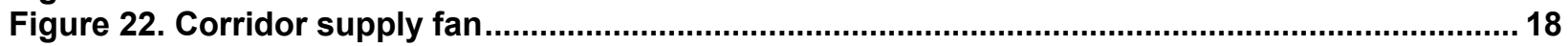

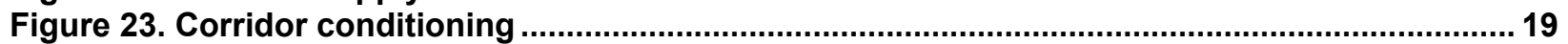

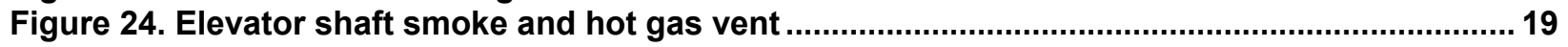

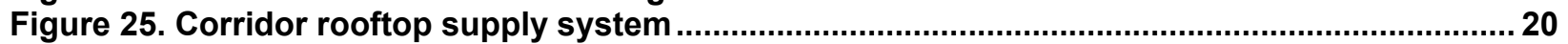

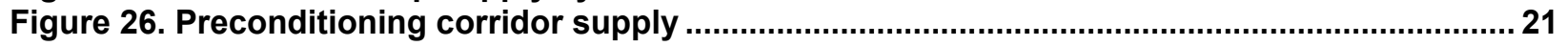

Figure 27. Trash chute-Should be maintained at a negative pressure ........................................... 22

Figure 28. Trash chute pressure control ................................................................................... 22

Figure 29. Forced air-Outside air to return to side of air handler.............................................. 24

Figure 30. Forced air-Outside air to return to side of air handler, supplemental dehumidification 
Figure 31. Forced air-Heat recovery ventilator/energy recovery ventilator.

Figure 32. Forced air-Heat recovery ventilator/energy recovery ventilator, supplemental dehumidification

Figure 33. Packaged terminal heat pump-Heat recovery ventilator/energy recovery ventilator.... 28

Figure 34. Packaged terminal heat pump-Heat recovery ventilator/energy recovery ventilator, supplemental dehumidification.

Figure 35. Radiant heating-Heat recovery ventilator/energy recovery ventilator...

Unless otherwise noted, all figures were created by Building Science Corporation. 


\section{Abbreviations}

ach air changes per hour

ASHRAE American Society of Heating, Refrigerating and Air-Conditioning Engineers

cfm cubic feet per minute

ERV energy recovery ventilator

HRV heat recovery ventilator

HVAC heating, ventilating, and air conditioning

IAQ indoor air quality

ICC International Code Council

IRC International Residential Code for One- and Two-Family Dwellings

PTHP packaged terminal heat pump 


\section{Abstract}

The measure guideline provides ventilation guidance for residential high-performance multifamily construction that incorporates the requirements of the ASHRAE 62.2 ventilation and indoor air quality standard. The measure guideline focus is on the decision criteria for weighing cost and performance of various ventilation systems.

The measure guideline is intended for contractors, builders, developers, designers, and building code officials. The guide may also be helpful to building owners wishing to learn more about ventilation strategies available for their buildings.

The measure guideline includes specific design and installation instructions for the most costand performance-effective solutions for multifamily unit ventilation that satisfy the requirements of ASHRAE 62.2-2016. 


\section{Progression Summary}

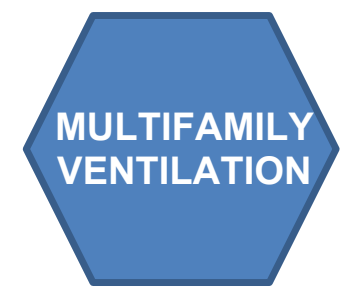

The following outlines the steps to consider when designing and installing multifamily building ventilation systems.

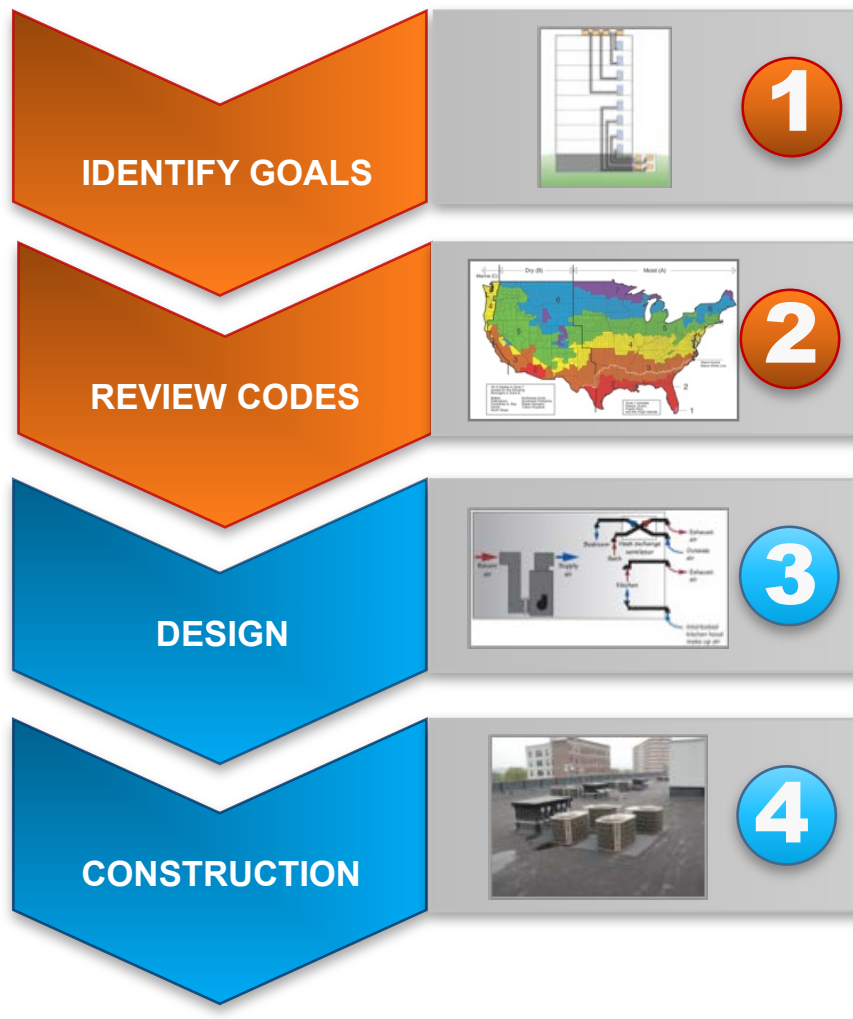

Identify project goals. Develop project goals with consideration given to health and safety, climate zone, energy performance and cost, and any other project-specific criteria or constraints.

Review building code requirements. Review the locally adopted building code for health and safety, fire, and minimum energy performance requirements.

Design. Decide on the ventilation system best suited to the project goals that will be required to implement the design. For moderate to large projects, consider engaging a qualified engineer to design the system.

Construction. Plan the installation process, including sequencing. 


\section{Introduction}

High degrees of enclosure air tightness and unit compartmentalization are fundamental components of high-performance multifamily construction and are now code required. Acceptable indoor air quality (IAQ) is also a fundamental component of high-performance construction, including requirements for dwelling unit mechanical ventilation. However, dwelling unit ventilation approaches that are compliant with ASHRAE Standard 62.2-2016 within enclosures constructed in accordance with the ICC 2015 International Residential Code (IRC) currently are not typical.

Exhaust-only and supply-only ventilation strategies can both be problematic in multifamily dwelling units that are constructed to meet the 2015 IRC or ASHRAE Standard 62.2-2016 air tightness requirements. Therefore, balanced ventilation strategies are strongly recommended for multifamily construction and have been shown to be effective.

This document provides guidance on balanced ventilation strategies for a variety of multifamily applications. Additionally, it addresses several other issues related to ventilation in highperformance multifamily construction, including kitchen exhaust and supplemental dehumidification.

These are significant changes to conventional ventilation practices due to current trends toward tighter construction and increased ventilation requirements. This measure guideline addresses each of these issues. 


\section{Decision-Making Criteria}

\subsection{Airtightness Requirements}

High degrees of enclosure air tightness and unit compartmentalization are fundamental components of high-performance construction, and recent building codes include minimum requirements for airtightness.

The 2015 IRC (N1102.4.1.2) requires building enclosures be tested to meet an airtightness performance metric of 3 ach@50 Pa or less in climate zones 3-8. The IRC does not distinguish between single-family detached construction and multifamily construction.

ASHRAE Standard 62.2-2016 requires an airtightness performance metric for multifamily units of no more than $0.3 \mathrm{cfm}$ per $\mathrm{ft}^{2}$ of the dwelling unit envelope area at a test pressure of $50 \mathrm{~Pa}$. The $0.3 \mathrm{cfm}$ per $\mathrm{ft}^{2}$ value was proposed by Lstiburek (2005).

Both of these metrics result in significantly greater enclosure tightness than conventional construction but are typical of high-performance single-family detached construction (Finch et. al. 2009; Maxwell et. al. 2014) and individual unit multifamily construction that meet model code fire- and smoke-control requirements and interunit acoustical control requirements (Lstiburek 2005).

\subsection{Ventilation Requirements}

Acceptable indoor air quality is also a fundamental component of high-performance construction and is also addressed in recent building codes with minimum dwelling unit and local exhaust ventilation requirements.

ASHRAE Standard 62.2-2016 requires a continuous ventilation rate of $45 \mathrm{cfm}$ for a onebedroom enclosure of 1,000 $\mathrm{ft}^{2}$ floor area. ASHRAE Standard 62.2-2016 only allows credit for infiltration in horizontally attached (i.e., low-rise) multifamily units.

Additionally, ASHRAE Standard 62.2-2016 requires a vented kitchen range hood with a minimum intermittent exhaust flow of $100 \mathrm{cfm}$ or local kitchen area intermittent ventilation of 5 ach. Bathroom exhaust is also required at a minimum intermittent rate of $50 \mathrm{cfm}$ or a continuous rate of $20 \mathrm{cfm}$.

\subsection{Implications for Multifamily Ventilation Design}

Multifamily construction has reduced exterior wall area and shared surface areas with neighboring units and common spaces, limiting the applicability of typical ventilation strategies.

Exhaust-only dwelling unit ventilation at the ASHRAE Standard 62.2-2016 rates can lead to significant depressurization in units that are constructed to meet the 2015 IRC or ASHRAE Standard 62.2-2016 airtightness requirements (CMHC 2005; Lstiburek 2013). This level of depressurization increases the risk of pulling air from neighboring units and corridors. Furthermore, current code restricts exhaust-only ventilation because it introduces lower-quality air from these adjacent spaces. Therefore, exhaust-only ventilation is not a recommended ventilation strategy for high-performance multifamily new construction. Exhaust-only ventilation 
with passive air inlets is also not recommended because passive air inlets have been shown to provide inadequate ventilation rates (U.S. Department of Energy 2015) (Maxwell et. al. 2014).

Supply-only dwelling unit ventilation for multifamily units at the ASHRAE Standard 62.2-2016 rates can lead to significant pressurization of units. This often has the unintended consequence of driving air into neighboring units and the resulting potential for odor and contaminant transfer. Therefore, balanced ventilation strategies are the only recommended strategies for most highperformance multifamily construction applications. The remainder of this document is focused on guidance for implementing balanced ventilation strategies in a variety of multifamily applications.

Horizontally attached low-rise multifamily dwelling units (e.g., row houses) are an exception because the common walls are the only shared building assemblies, which reduces risk of intraunit communication. In these building types, unbalanced ventilation may work if make-up air is provided for large exhaust fans (e.g., kitchen range hoods and vented clothes dryers).

Additionally, exhaust-vented kitchen range hoods in multifamily construction are only effective with interlocked powered make-up air. Local kitchen area ventilation of 5 ach is proving problematic, as no enforceble definition of "local" has been provided.

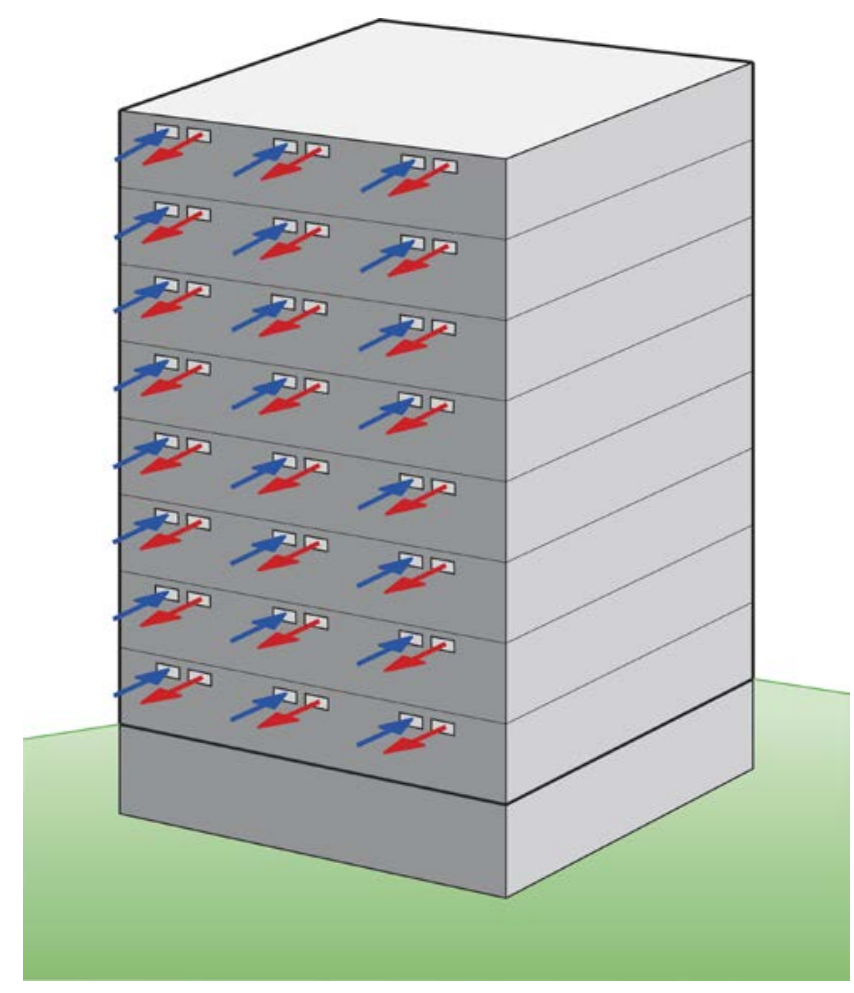

Figure 1. Only balanced ventilation strategies are recommended for most multifamily construction

Installation of clothes dryers that are vented to the exterior also leads to significant depressurization in multifamily units. Clothes dryer exhaust rates are typically $200 \mathrm{cfm}$ or more. Interlocked powered make-up air is necessary; alternatively, unvented condensing clothes dryers must be used. 
Intermittent bathroom exhaust at $50 \mathrm{cfm}$ in multifamily units is also problematic without provision for make-up air.

In warm-humid climates, supplemental dehumidification is necessary in energy efficient homes that have dramatically reduced sensible cooling loads (Rudd 2013). The issue is particularly acute in tighter multifamily units ventilated at relatively high ventilation rates such as those required by ASHRAE Standard 62.2-2016.

\subsection{System Selection: Advantages, Disadvantages, and Costs}

Each of the balanced ventilation system options presented in this measure guideline has advantages, disadvantages, and costs. In almost all cases the advantages, disadvantages, and costs are subjective rather than objective after minimum requirements are met.

For example, the choice of supplemental dehumidification is made by climate location. It is the only viable option in hot-humid and mixed-humid climates. No air conditioning systems currently exist that have sufficient dehumidification capability for multifamily units ventilated at ASHRAE Standard 62.2-2016 rates. Separate systems are required.

The choice of forced air vs. radiant is typically a regional choice. Radiant heating with no cooling is a Pacific Northwest approach to multifamily unit space conditioning. One method of providing balanced ventilation in such units is with a heat recovery ventilator (HRV) or an energy recovery ventilator (ERV). Balanced ventilation system units are commercially available without heat recovery or energy recovery. The advantage of heat recovery or energy recovery is higher energy performance.

In cases where a forced-air system with air conditioning is compared with packaged terminal heat pumps (PTHPs), little agreement exists. The cost of a ducted forced-air system with outside air connected to the return side of the air handler coupled to an exhaust system in the bathroom(s) is similar to a ducted HRV or ERV providing the balanced ventilation with a PTHP. One has heat recovery/energy recovery and the other does not. It can be argued that since the costs are similar, the HRV/ERV has an advantage due to the obvious energy savings. The counterargument is that maintenance and durability issues with a more complex system, such as an HRV/ERV, are not worth the energy advantage, and the forced-air system coupled to an exhaust system is viewed by others as preferable due to lower cost and less ductwork.

Where forced-air systems are preferred by the marketplace (typically a regional bias), a standalone HRV/ERV that does not interact with the forced-air system is viewed by some as a less complicated system to install and maintain than integrating the ventilation system with the forced-air system. 


\section{Technical Description}

\subsection{Purpose of Ventilation}

Ventilation is one component of an integrated approach to providing acceptable IAQ in buildings that includes source control of contaminants and environmental separation (the "building or unit enclosure"). Acceptable IAQ includes control of temperature and odors. Ventilation is the intentional exchange of air between the outside of a building and the inside.

\subsection{Uniqueness of Multifamily Construction}

Multifamily units share common surface areas with neighboring units (Figure 2). Ventilation air should not be pulled from neighboring units, for fire- and smoke-control, odor-control, and general IAQ reasons.

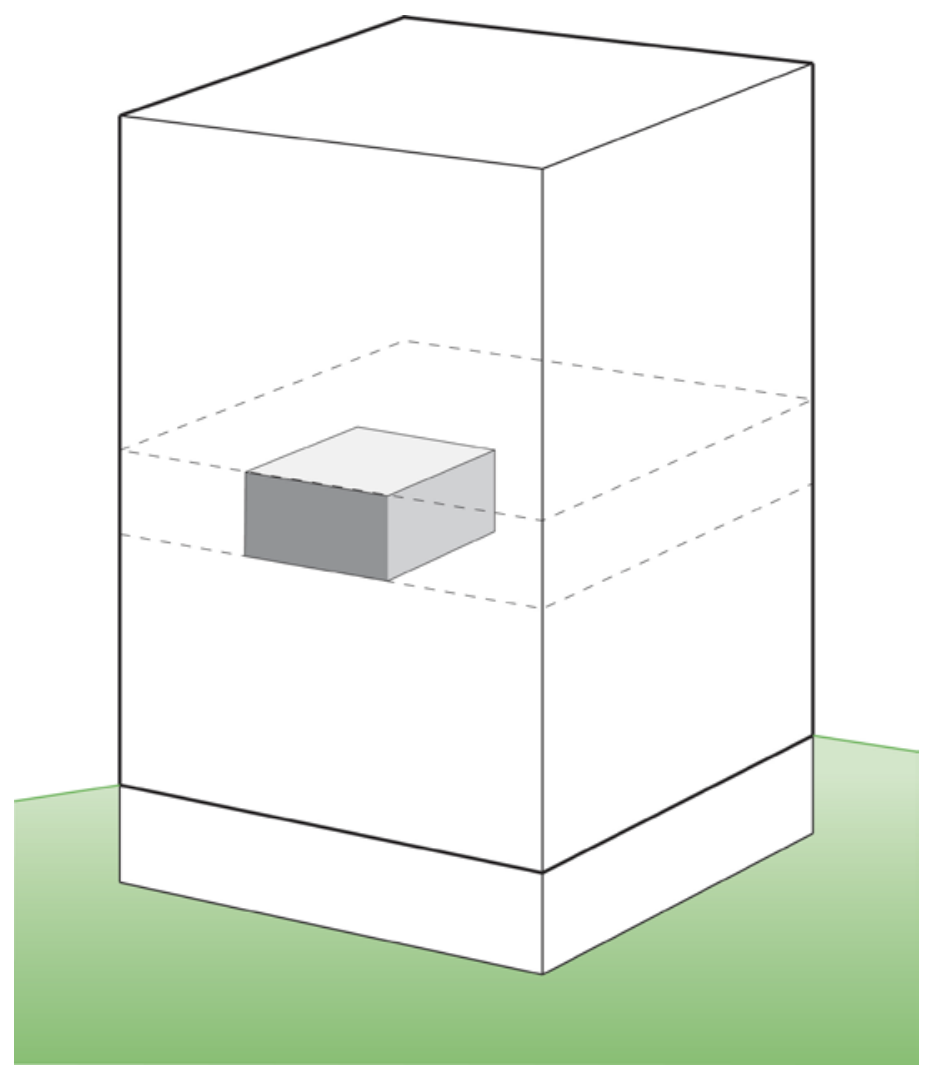

Figure 2. Multifamily construction-Multifamily units share common surface areas with neighboring units. Ventilation air should not be pulled from neighboring units, for fire- and smokecontrol, odor-control, and general IAQ reasons

To prevent air from transferring between multifamily units, high levels of air tightness are required, as is the control of air pressure differentials. Common walls are also required to meet fire and smoke assembly requirements (Figure 3). Most floor assemblies in multifamily frame construction are soundproofed and fireproofed with liquid gypsum subflooring (Figure 4) that results in airtight wall assemblies at floor-to-wall connections. 


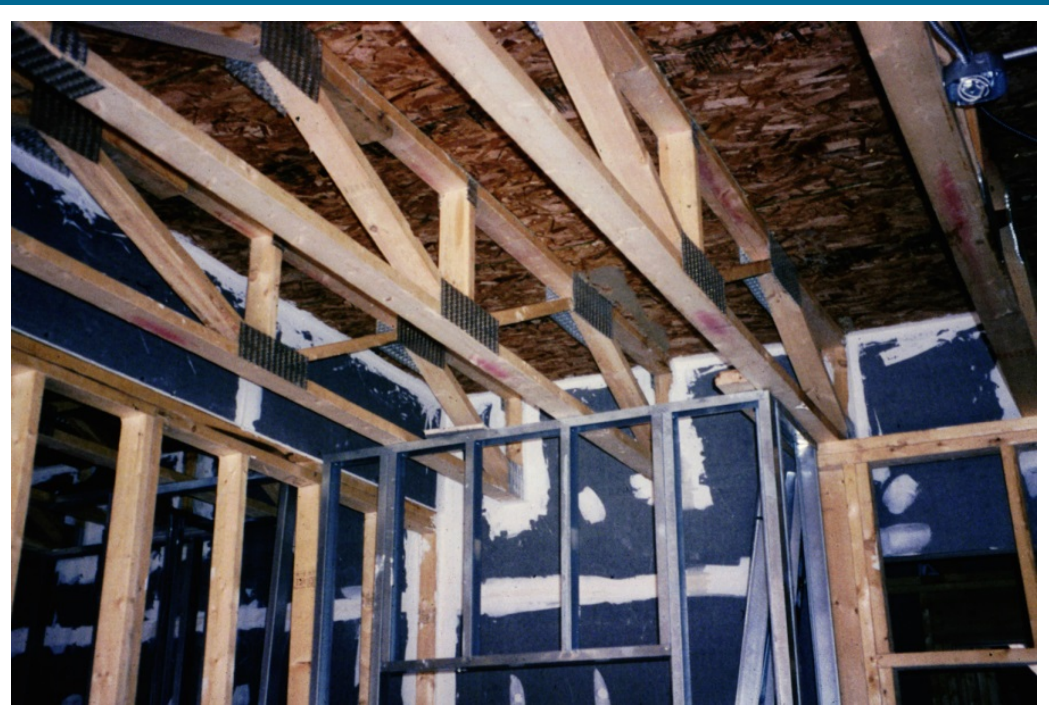

Figure 3. Common wall construction-Common walls are required to meet fire and smoke assembly requirements

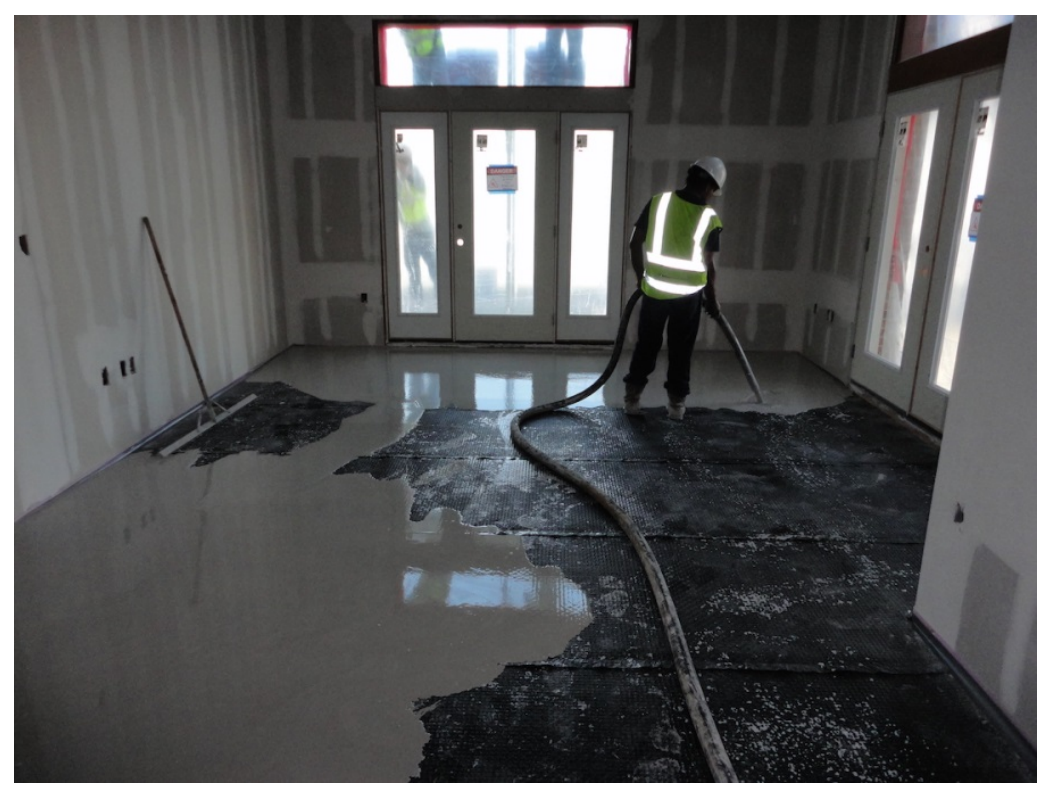

Figure 4. Floor assembly air sealing-Floor assemblies that are soundproofed and fireproofed with liquid gypsum subflooring result in airtight wall assemblies at floor to wall connections

Ventilation air is prohibited by model codes from being introduced into multifamily units from corridors. Doors from multifamily units to corridors are typically weatherstripped (Figure 5). 




Figure 5. Weatherstripped corridor doors-Ventilation air is prohibited from being introduced into multifamily units from corridors; doors from multifamily units to corridors are typically weatherstripped

Ventilation air can only be introduced into multifamily units by infiltration through exterior walls or directly into the units by ducted supply or passive air inlets (holes in the exterior walls [Figure 6]) or slotted vents in windows.

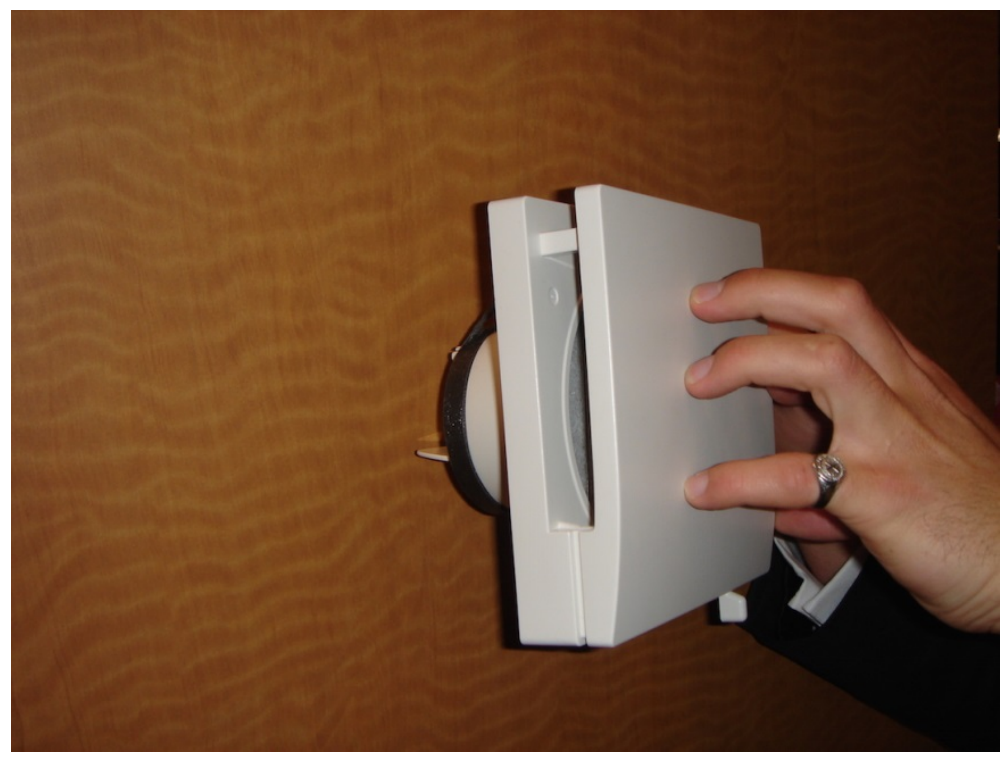

Figure 6. Passive air inlet-Ventilation air can only be introduced into multifamily units by infiltration through exterior walls or directly into the units by ducted supply or passive air inlets (holes in the exterior walls)

In multistory construction, stack-effect-driven airflows in buildings compromise smoke control and fire safety, adversely affect IAQ and comfort, and increase operating costs for space conditioning energy (Figure 7). The air in lower units ends up in the upper units (Figure 8). 


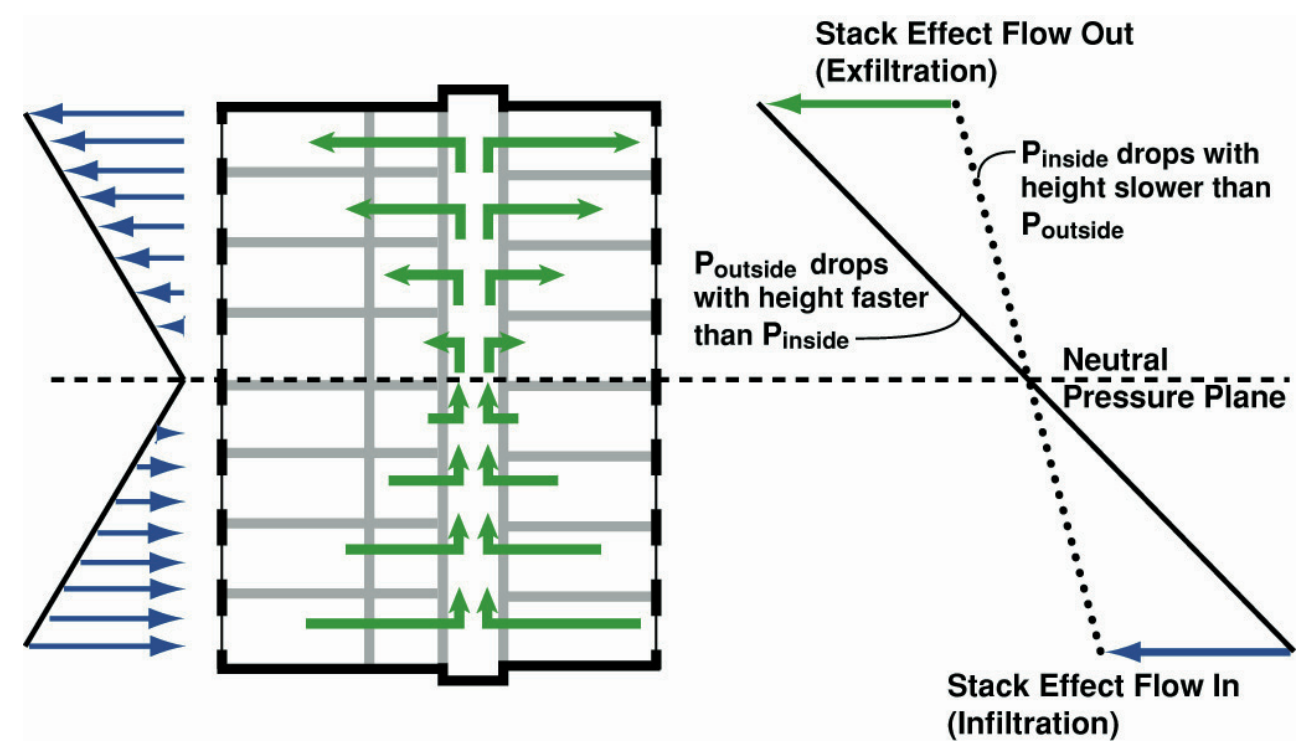

Figure 7. Stack effect in a multistory building-Stack-effect-driven airflows in multistory buildings compromise smoke control and fire safety, adversely affect IAQ and comfort and increase operating costs for space conditioning energy

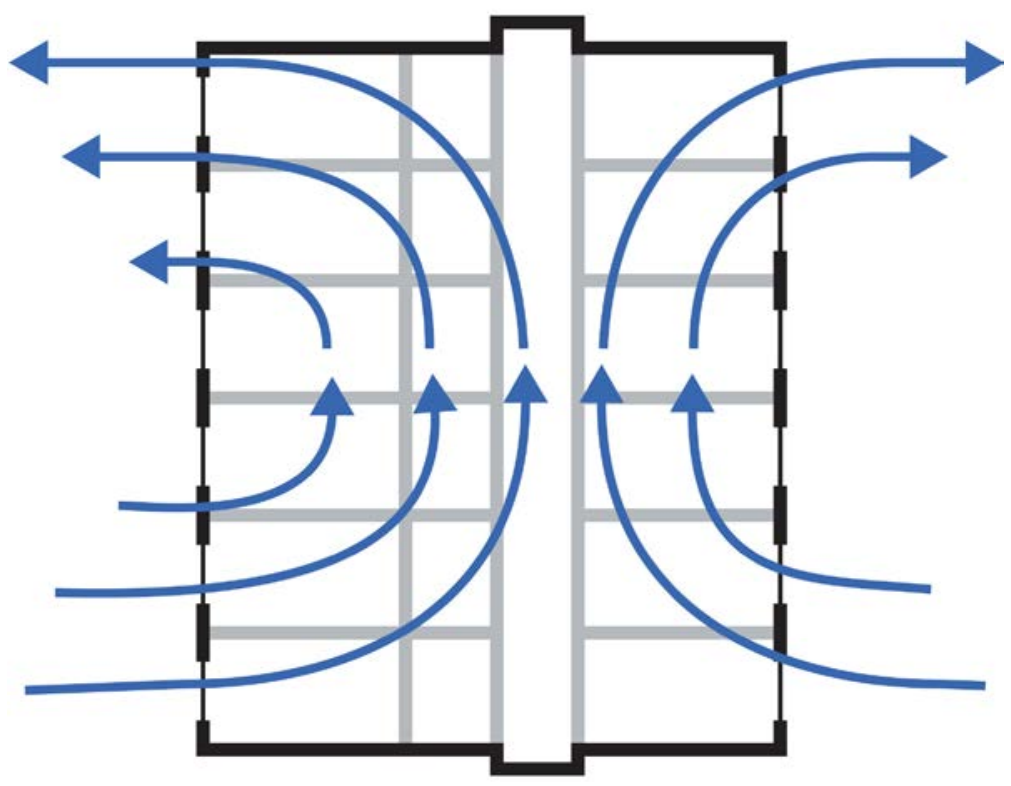

Figure 8. Stack-effect-driven airflow-The air in lower units ends up in the upper units

Stack-effect-driven interior airflows can be controlled by isolating the units from each other and from corridors, shafts, elevators, and stairwells (Figure 9). This is referred to as compartmentalization (Lstiburek 2005). The most elegant argument for compartmentalization of multistory buildings comes from Handegord (2001). Lower units should not supply air to upper units. 


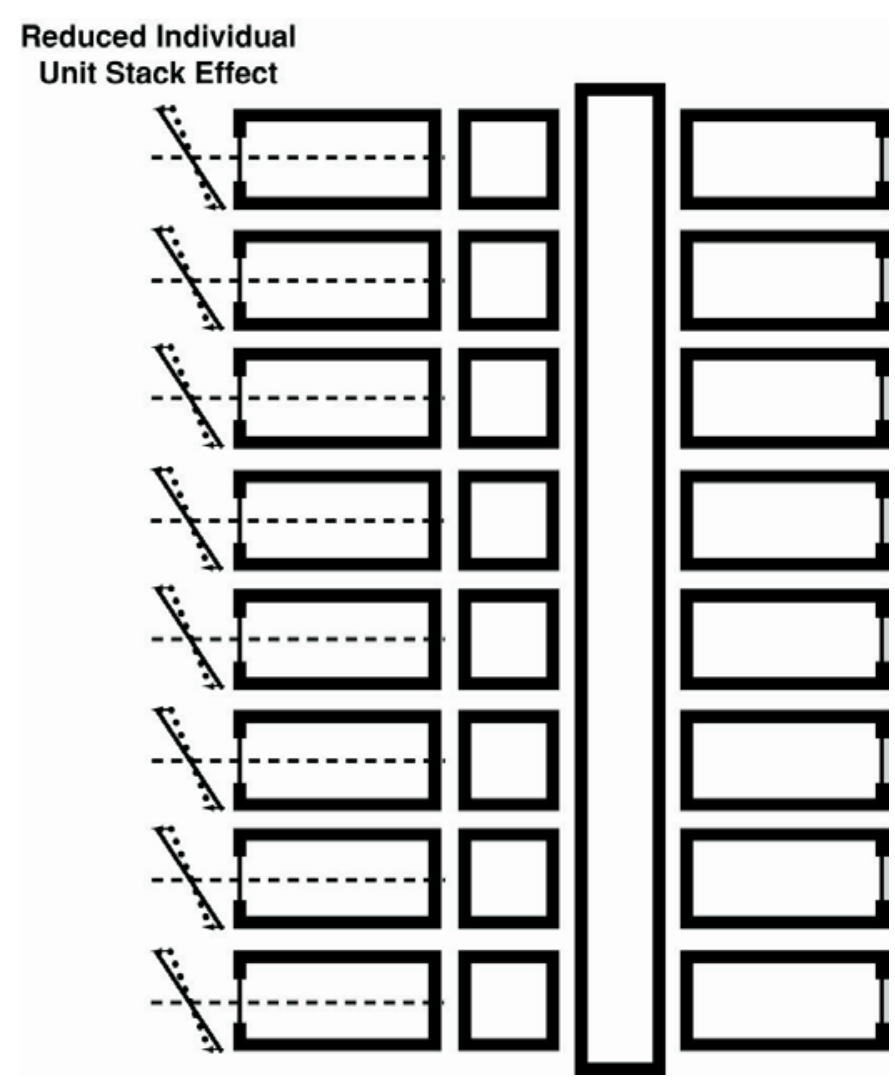

Figure 9. Compartmentalization-Basically, you turn a 10-story building into 10 one-story buildings that are stacked on top of one another; by isolating the units from each other and from corridors, shafts, elevators, and stairwells, stack-effect-driven interior airflows can be controlled

Central systems that move air between units and floors for ventilation purposes result in multifamily units that do not meet the ASHRAE or IRC airtightness requirements, cannot achieve dwelling unit compartmentalization, and can lead to IAQ and odor-control problems between dwelling units.

\subsection{Balanced Ventilation System Options}

Each system presented in this measure guideline is balanced and has provision for powered make-up air for vented kitchen range hoods and bathroom exhaust. Each system is designed to operate in a compartmentalized multifamily unit and with distributed heating and cooling systems (Figure 10, Figure 11, Figure 12, and Figure 13) or central systems where only hot water or chilled water or refrigerant is distributed, not air. 


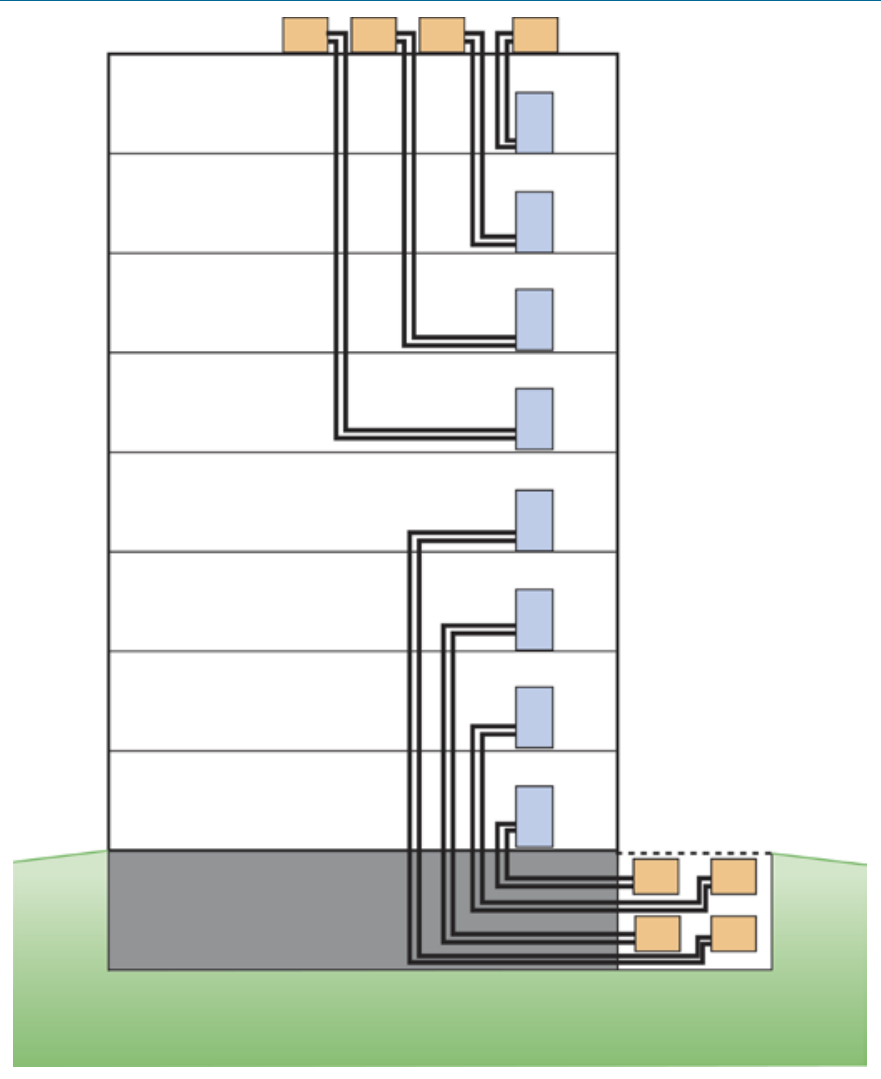

Figure 10. Distributed heating and cooling systems-Each unit is conditioned individually

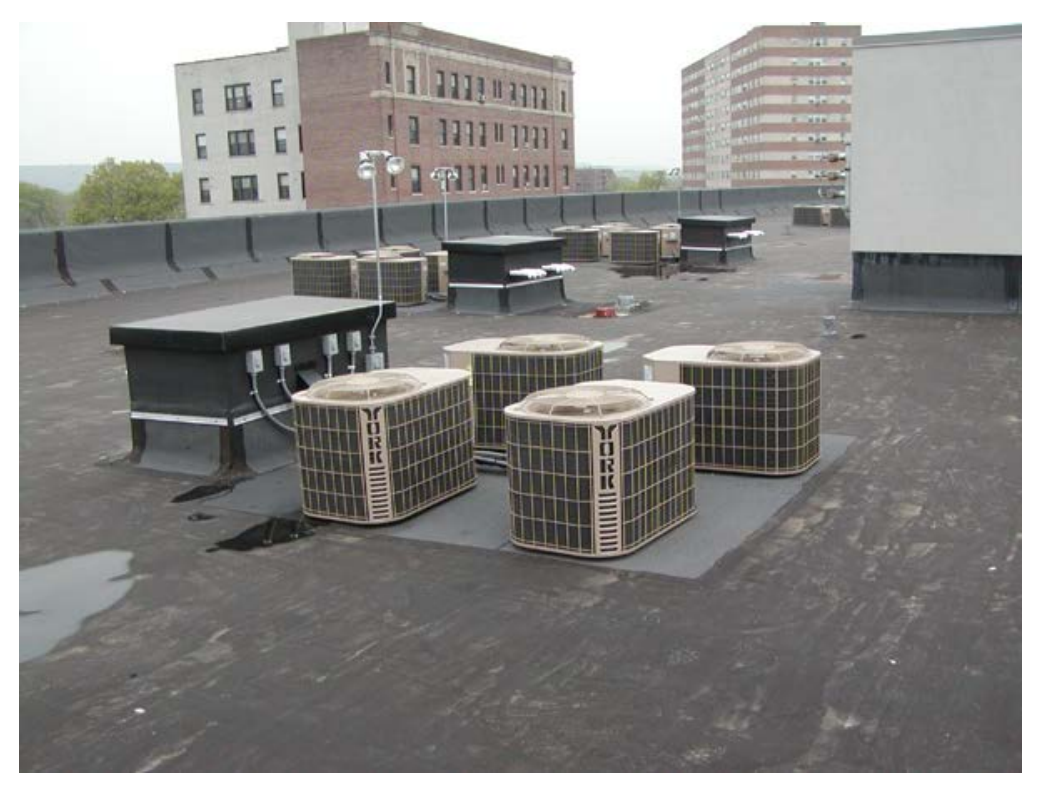

Figure 11. Distributed heating and cooling systems-Each unit is conditioned individually 


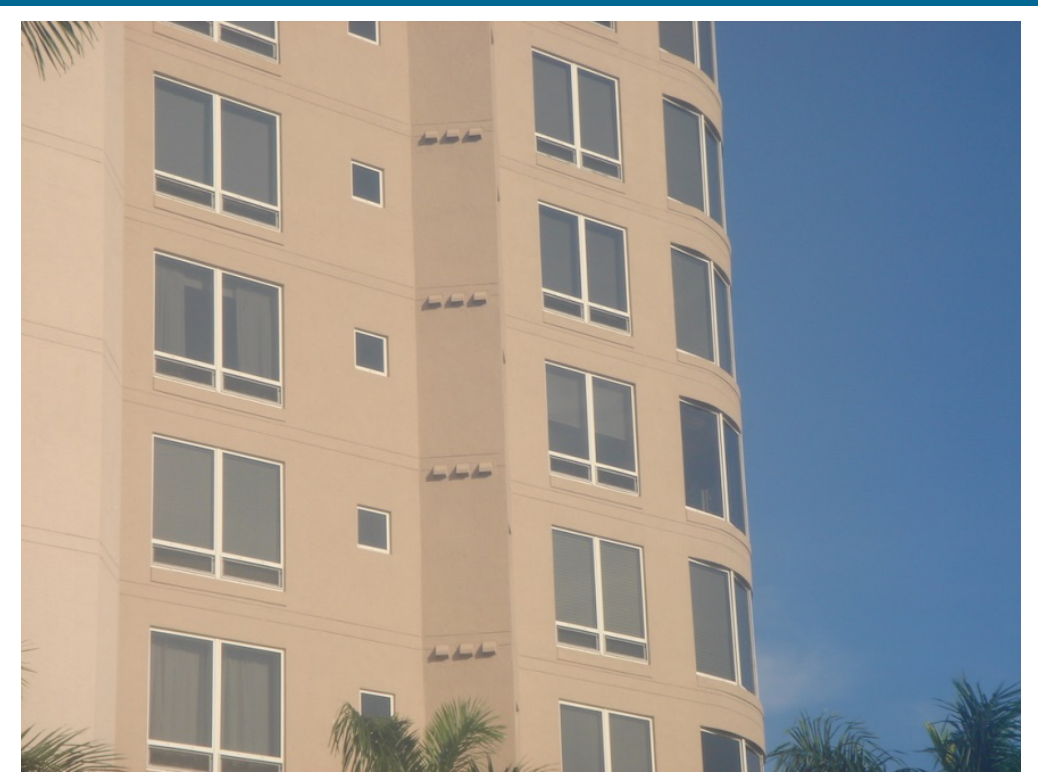

Figure 12. Individual supply and exhaust openings-Multiple exhaust grilles and supply grilles are required

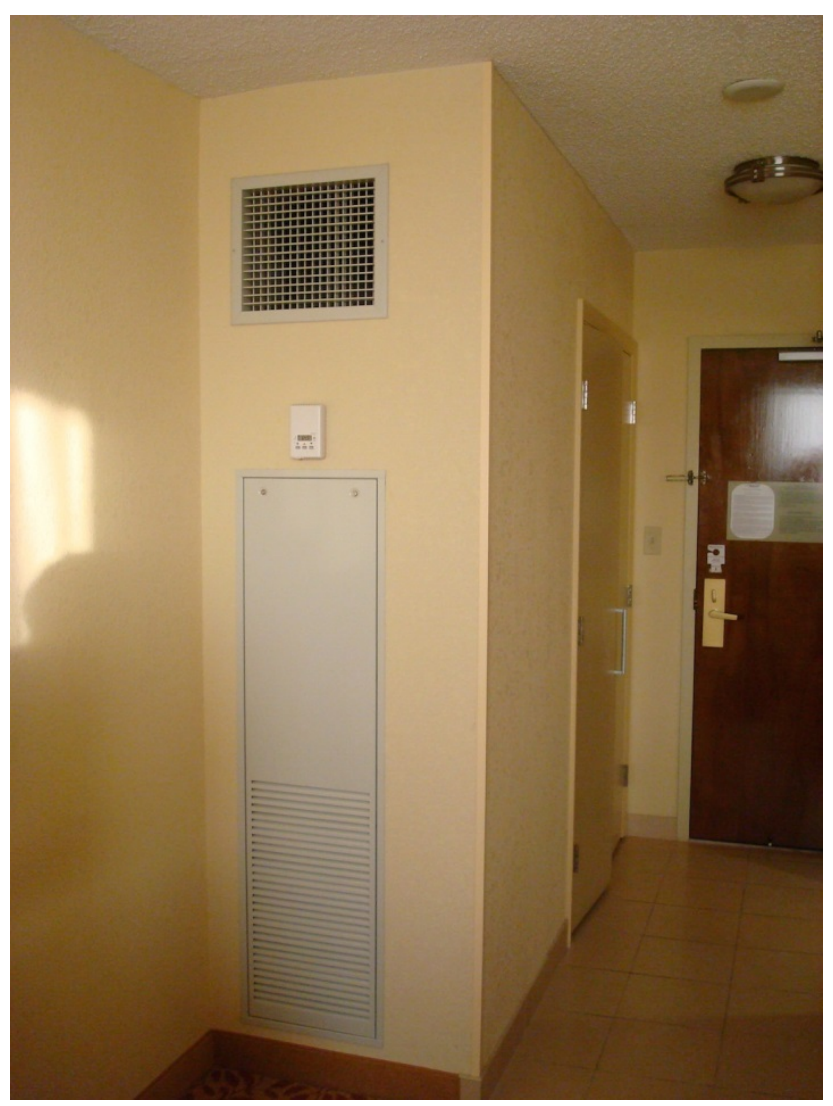

Figure 13. Individual unit space conditioning-Each unit has its own air distribution system

Electric water heaters (Figure 14) do not need to be vented to the exterior, whereas gas water heaters do. Gas water heaters should be sealed combustion two-pipe systems vented directly to 
the exterior with combustion air ducted directly to the water heater (Figure 15). Similarly, gas furnaces should be sealed combustion two-pipe systems.

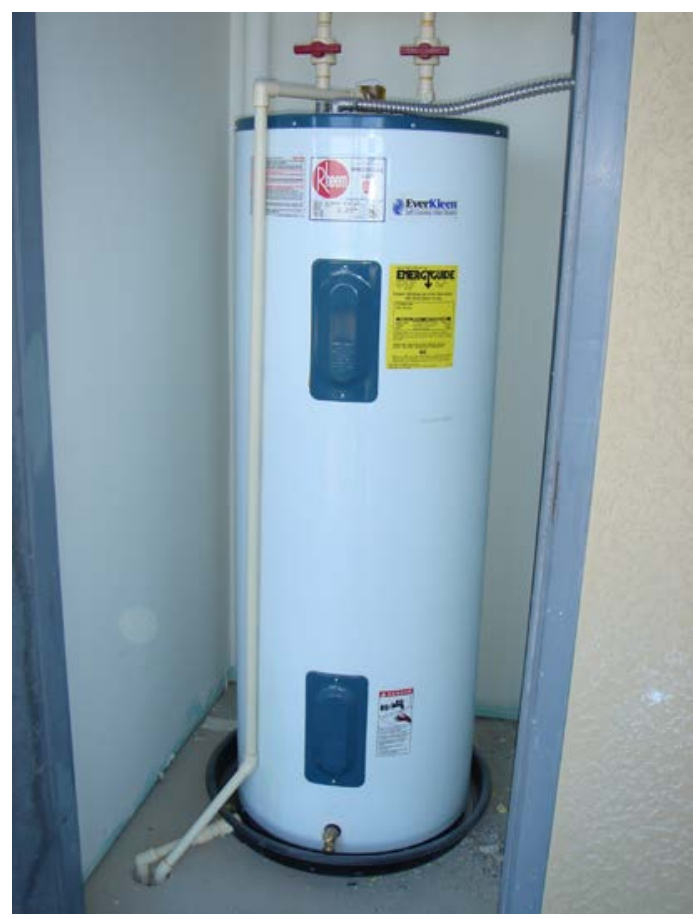

Figure 14. Electric water heater-Electric water heaters do not need to be vented to the exterior, whereas gas water heaters do

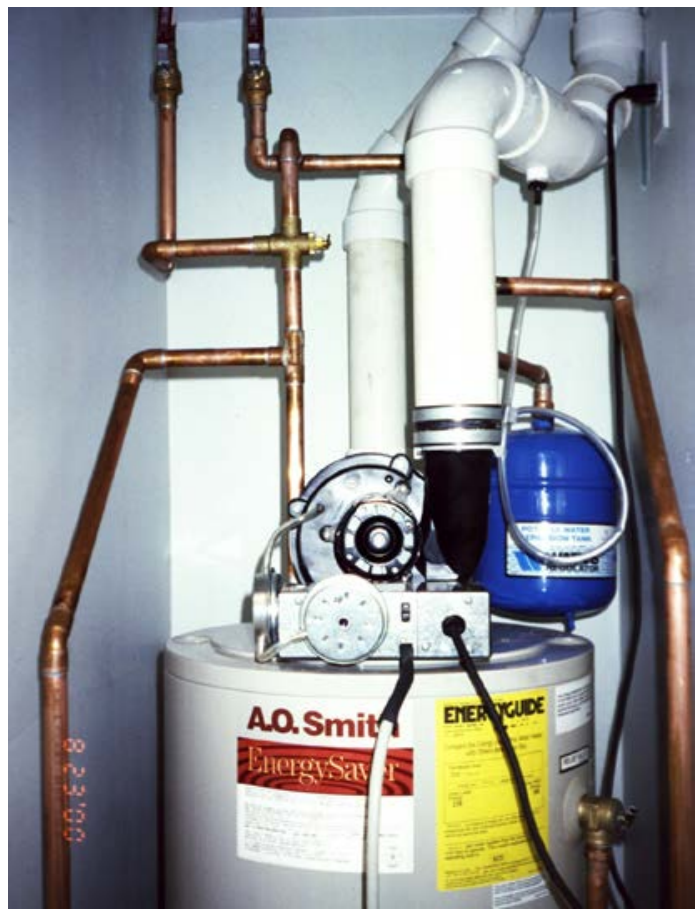

Figure 15. Gas water heater-Gas water heaters should be sealed combustion two-pipe systems vented directly to the exterior with combustion air ducted directly to the water heater 
Where clothes dryers are installed, they should be unvented condensing units (Figure 16) —or if vented to the exterior, a provision for powered make-up air must be provided.

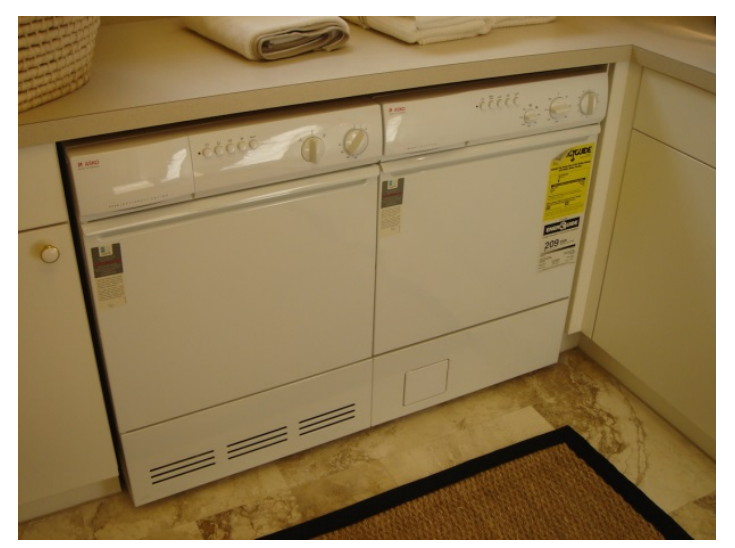

Figure 16. Clothes dryers-Where clothes dryers are installed, they should be unvented condensing units-or if vented to the exterior, a provision for powered make-up air must be made

The ventilation efficiency of kitchen range hoods is determined by the size of the hood. The larger the hood compared to the cooking surface, the higher the capture efficiency of the contaminant plume. It is recommended that make-up air be introduced below the cooking surface and that the range hood be wider and deeper than the cooking surface (Figure 17). Where this approach is used, the volume flow rate of kitchen range hood exhaust can be reduced (ASHRAE 2011).

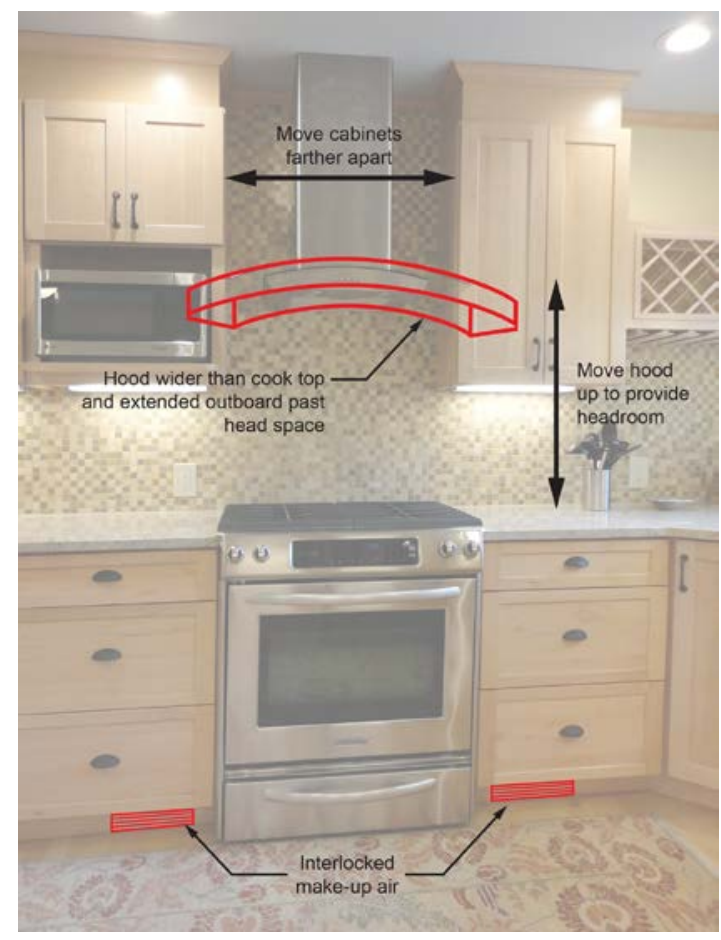

Figure 17. Kitchen range hood-It is recommended that make-up air be introduced below the cooking surface and that the range hood be wider and deeper than the cooking surface 
In hot-humid climates and mixed-humid climates, part load humidity cannot be controlled without supplemental dehumidification (Rudd 2013). This can be accomplished with stand-alone dehumidifiers (Figure 18, Figure 19, Figure 20, and Figure 21).

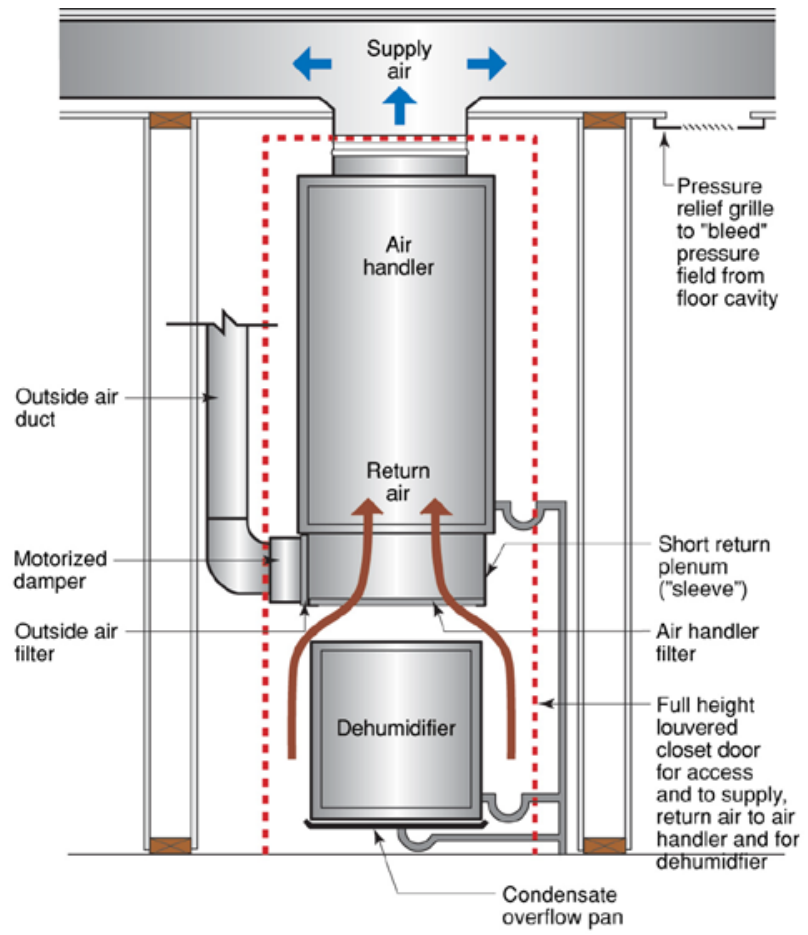

Figure 18. Dehumidifier-In return closet of forced-air system

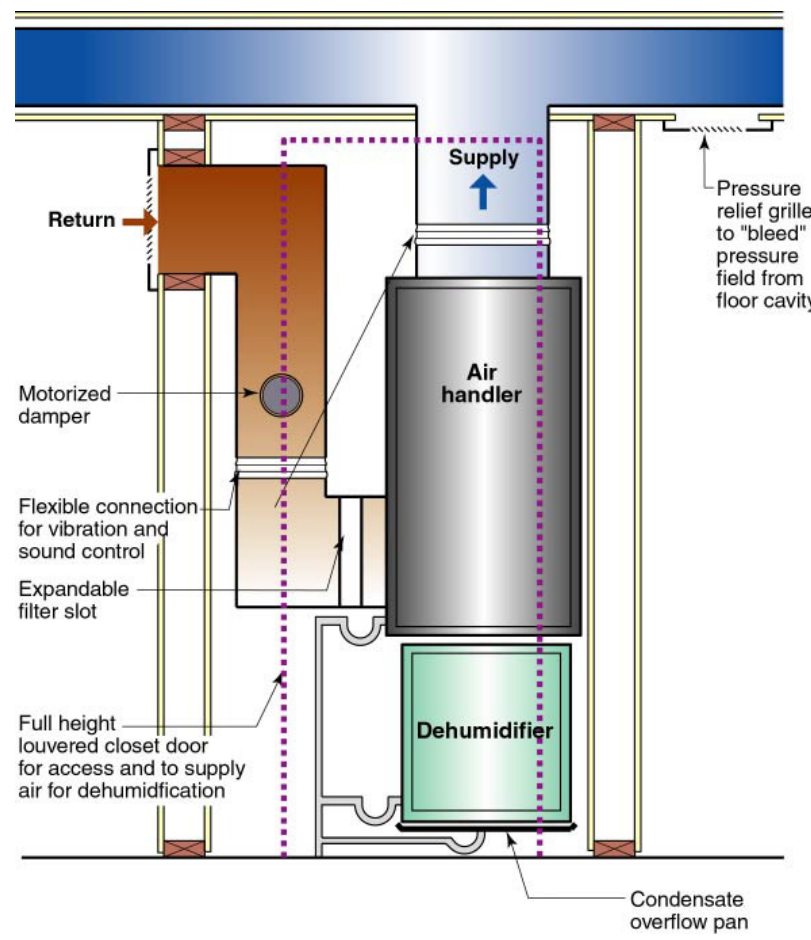

Figure 19. Dehumidifier—In ducted return system 




Figure 20. Dehumidifier-Located in return closet

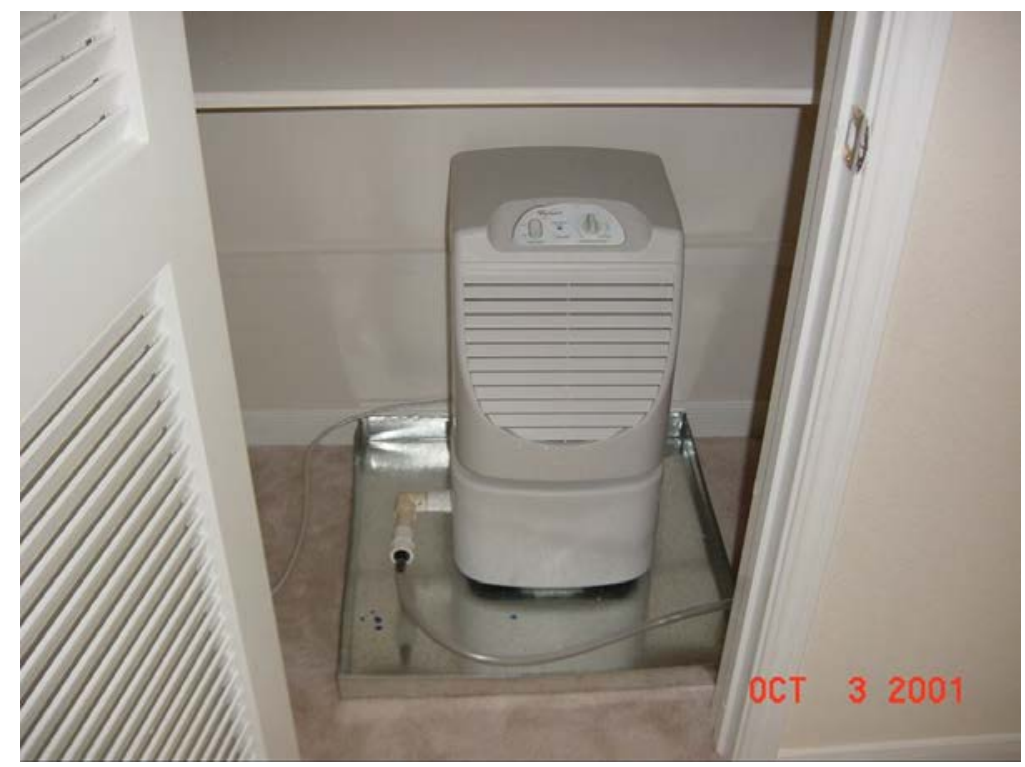

Figure 21. Dehumidifier-Located in closet with louvered door 


\subsection{Corridors, Elevator Shafts, and Trash Chutes}

When multifamily compartmentalization is executed, the corridors and elevator shafts are ventilated independently, as are trash chutes.

Corridors are required to be ventilated, according to ASHRAE Standard 62.1. ASHRAE Standard 62.2 does not have jurisdiction for corridors - just the individual multifamily units. Additionally, elevator shafts are governed by the International Mechanical Code.

The amount of ventilation required for a typical corridor is rather small — on the order of 20 or 30 cfm. This can be accomplished by providing a supply fan to each corridor (Figure 22). This supply air can be tempered by mixing with the air in the corridor. The supply air serves to pressurize the corridor. Corridor conditioning is typically provided at corridor ends (Figure 23).

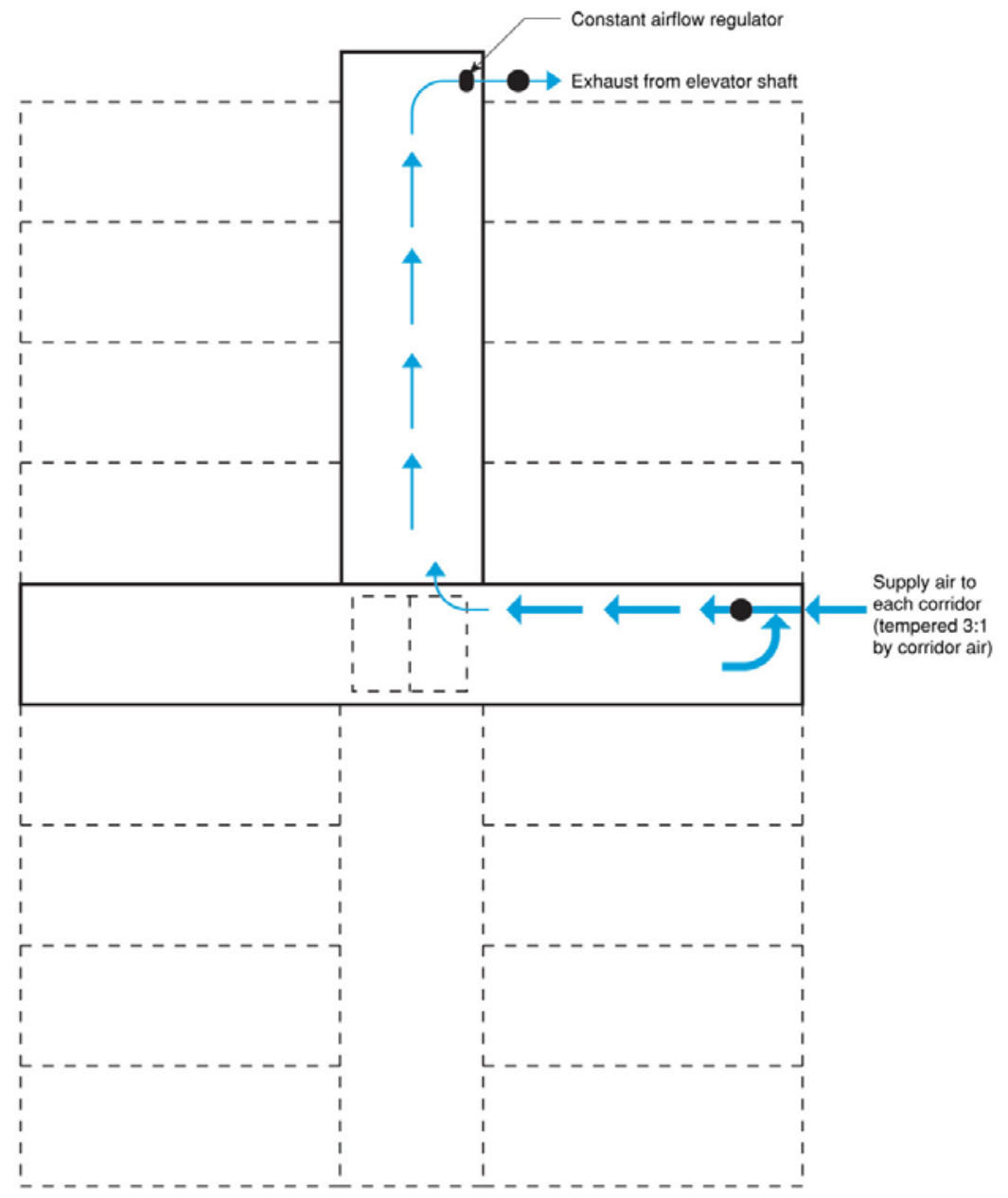

Figure 22. Corridor supply fan 


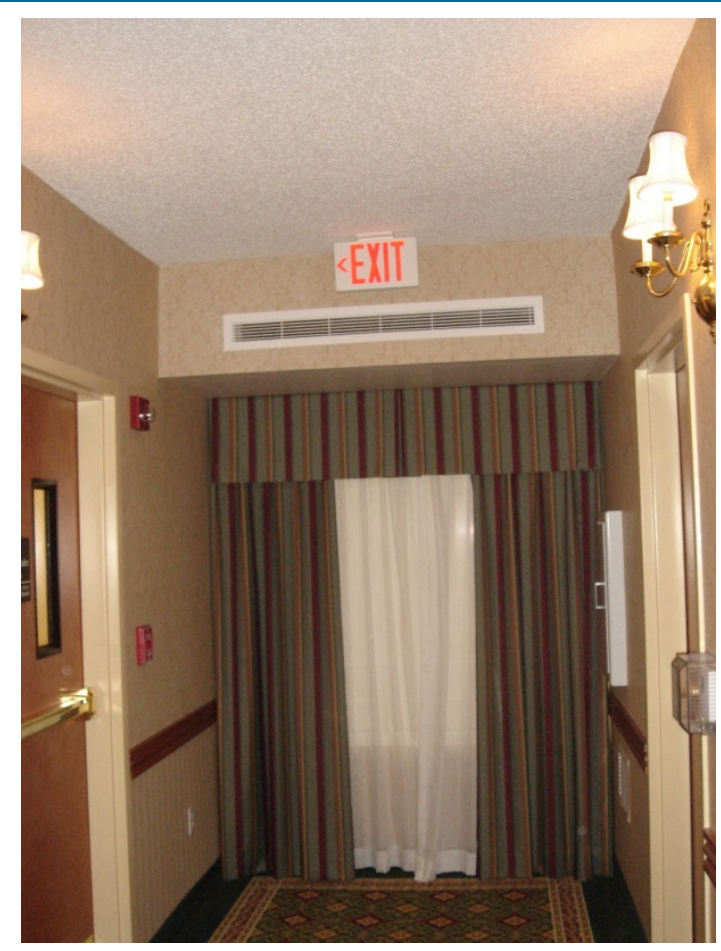

Figure 23. Corridor conditioning

Elevator shafts are typically depressurized with a rooftop fan whose exhaust flow is controlled by a constant airflow regulator to compensate for seasonal stack-effect variation. Supply air to the corridors is removed by exhaust air from the elevator shaft.

The model codes typically require elevator shafts to have a smoke and hot gas vent. This vent should have a motorized damper connected to the fire control system (Figure 24). This vent should be closed under typical operation to prevent uncontrolled airflow.

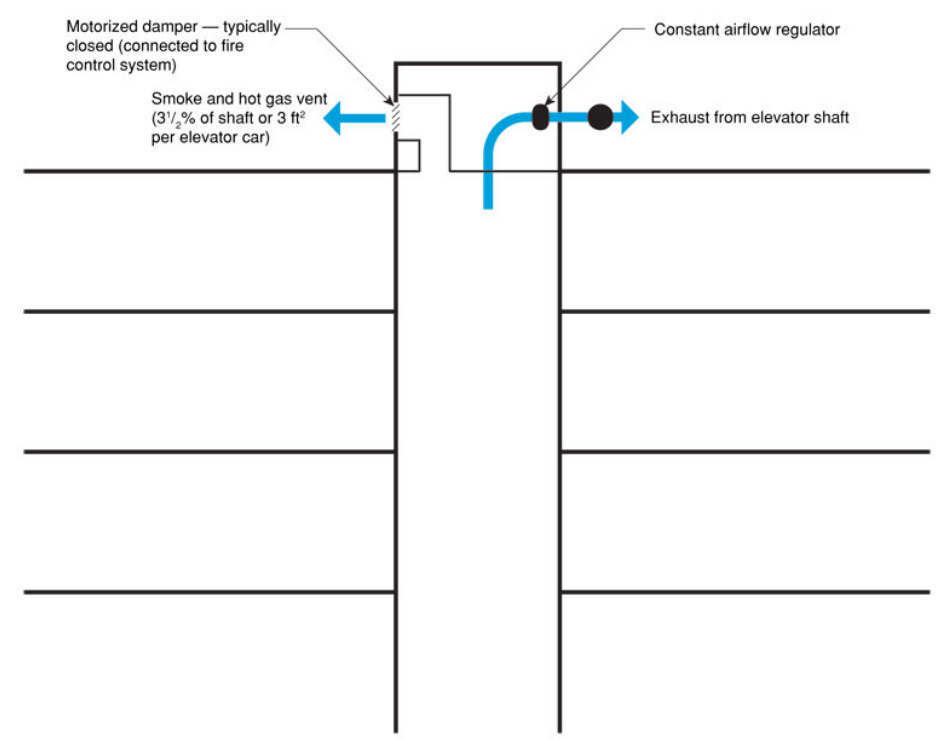

Figure 24. Elevator shaft smoke and hot gas vent 
Individual corridor supply fans can be replaced by a central rooftop system that supplies ventilation air to each corridor (Figure 25). In extreme cold or extreme hot-humid climates, the central system is typically combined with a preconditioning unit (Figure 26).

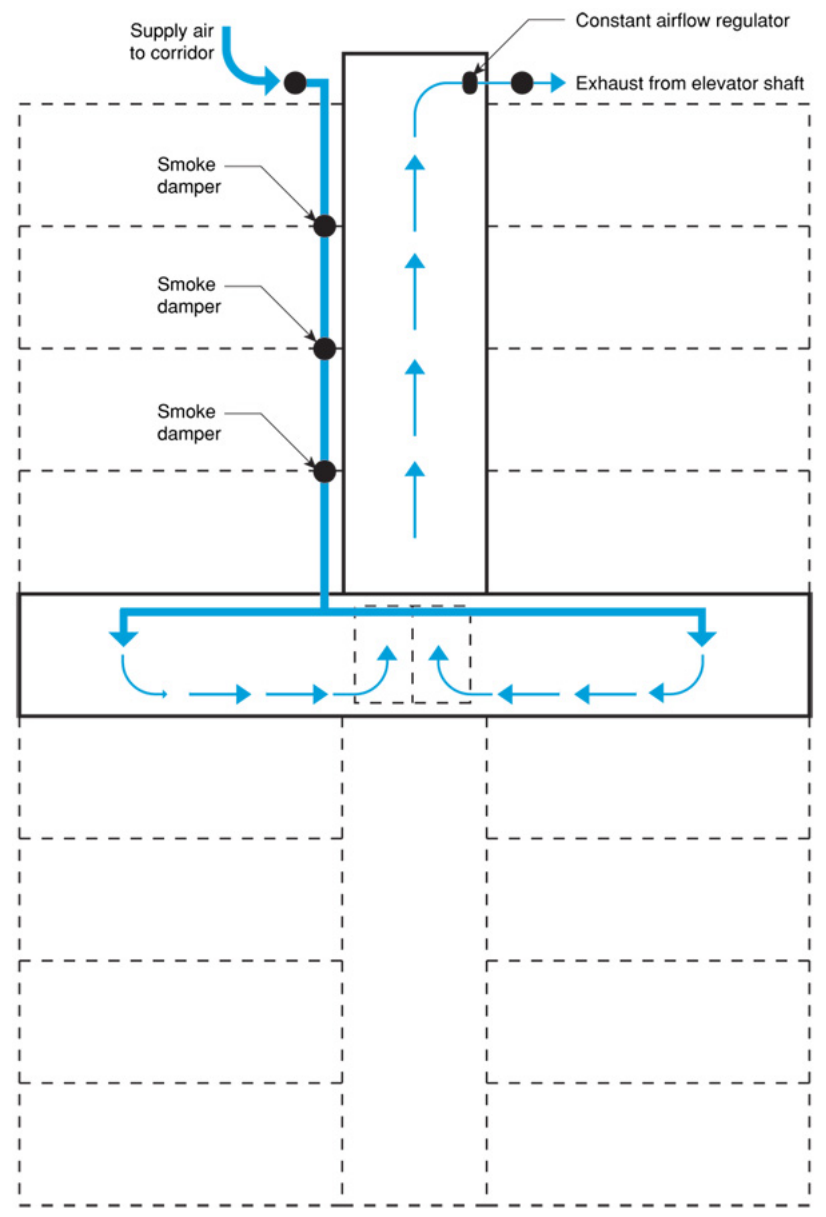

Figure 25. Corridor rooftop supply system 


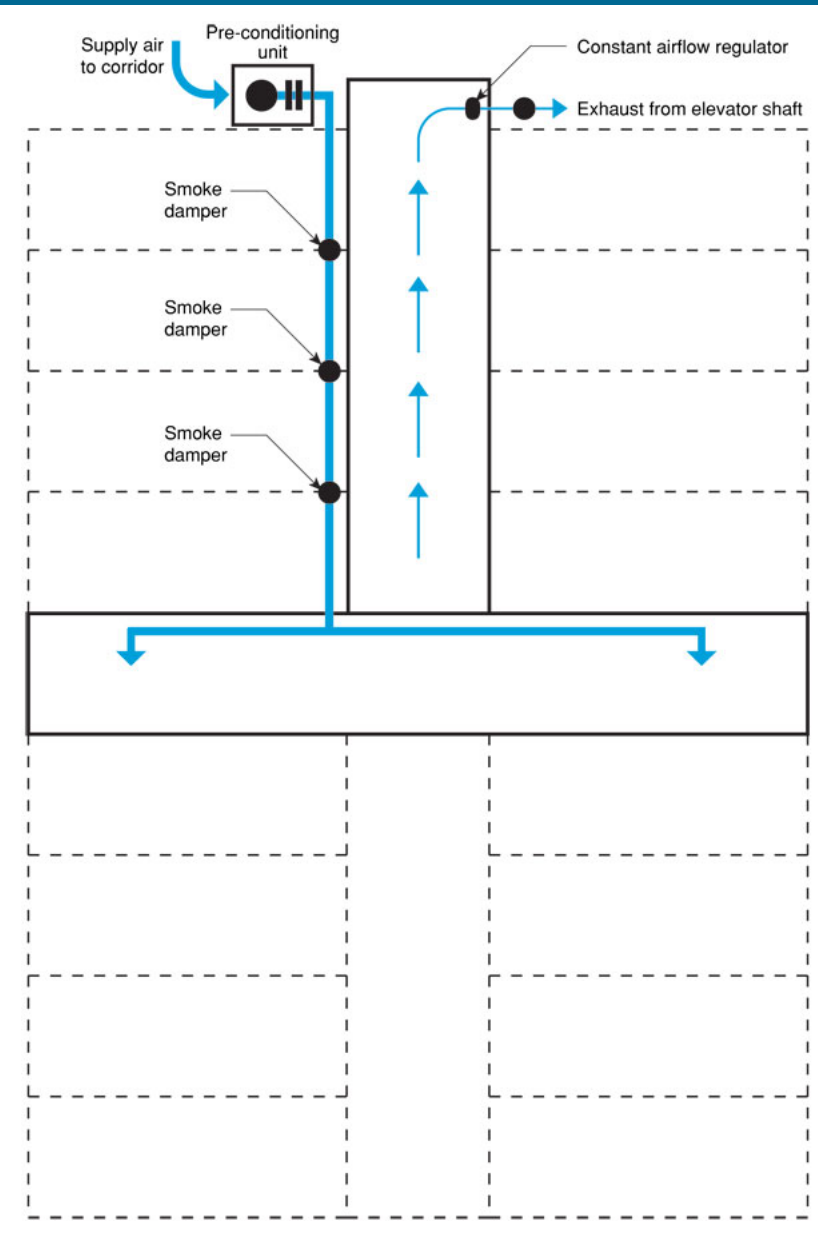

Figure 26. Preconditioning corridor supply

Trash chutes (Figure 27) should be depressurized to control odors as should trash rooms (Figure 28). 


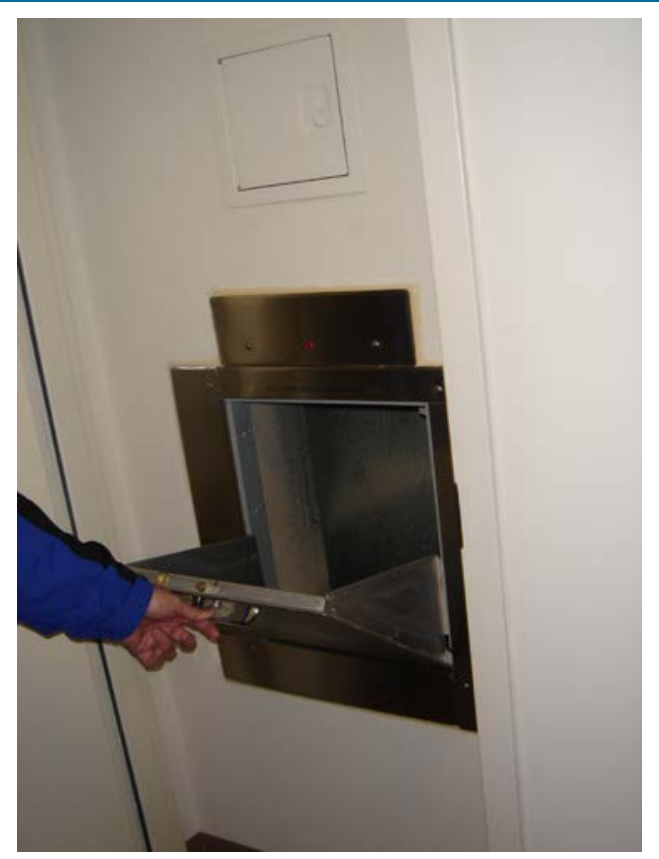

Figure 27. Trash chute-Should be maintained at a negative pressure

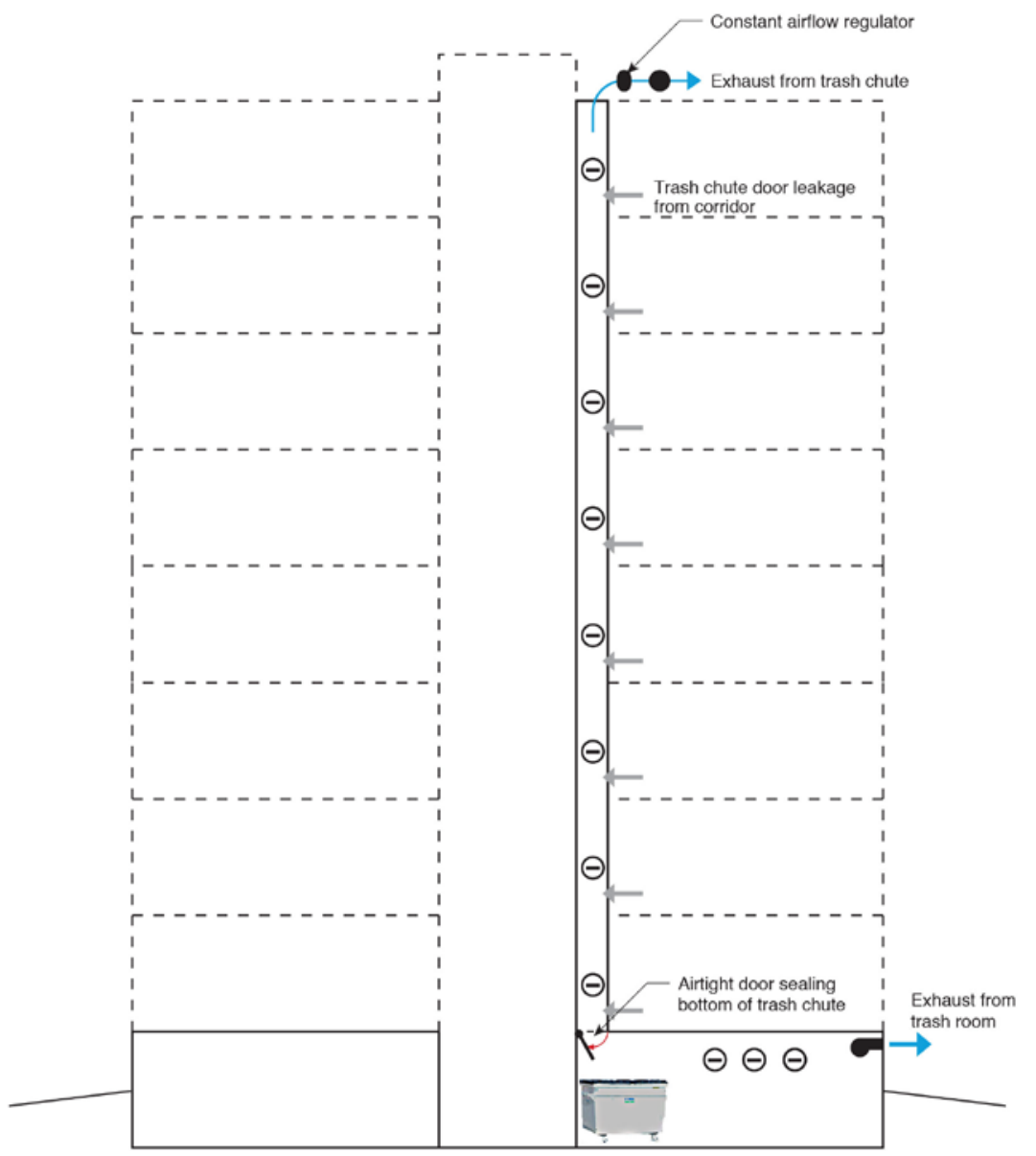

Figure 28. Trash chute pressure control 


\section{Measure Implementation}

Various ventilation system options are presented. Each system is balanced and has provision for powered make-up air for vented kitchen range hoods and bathroom exhaust. Each system is designed to operate in a compartmentalized multifamily unit and with distributed heating and cooling systems or central systems where only hot water or chilled water or refrigerant is distributed, not air.

\subsection{Climate-Specific Factors}

In warm-humid climates, supplemental dehumidification may be necessary in energy efficient homes where the sensible cooling load has been dramatically reduced (Rudd 2013). The issue is particularly acute in multifamily units ventilated at high rates.

\subsection{Field Inspection}

Ventilation system flows should be verified. Control systems should be clearly identified. Operating instructions should be provided to the occupant. Scheduled maintenance guidance should be included in occupant information. 


\section{System 1: Forced Air-Outside Air to Return Side of Air Handler}

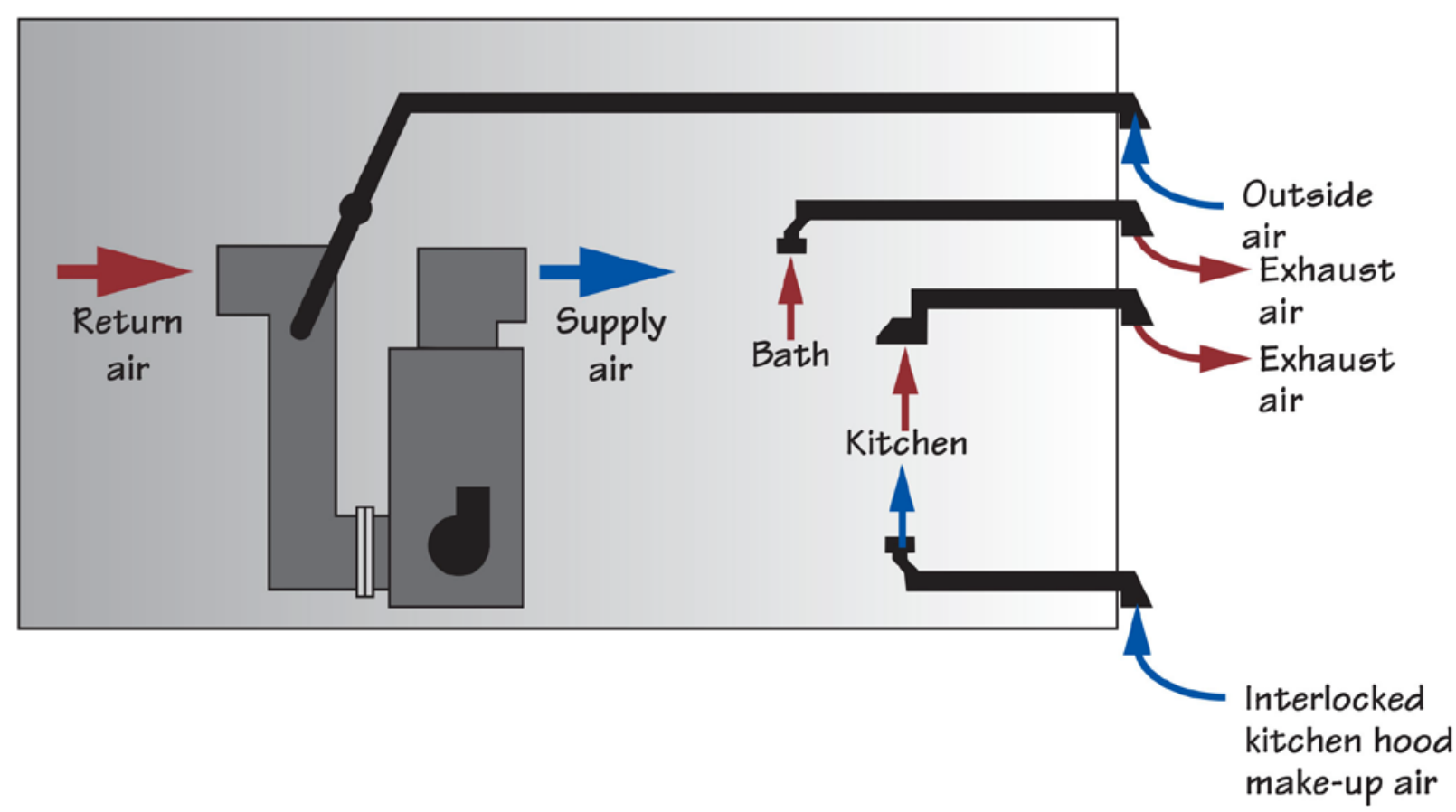

Figure 29. Forced air-Outside air to return to side of air handler

An outside air duct is connected to the return side of the air handler, and the air handler operates continuously. The air handler is interlocked with a continuous bathroom exhaust fan. The ventilation rate is set according to ASHRAE Standard 62.2. The rate at which outside air is brought in through the outside air duct is matched by the exhaust rate of the bathroom exhaust. For example, if $45 \mathrm{cfm}$ is supplied via the outside air duct, then the bathroom fan exhausts continuously at a rate of $45 \mathrm{cfm}$. If two bathrooms are in the unit, the exhaust rate is split between the two bathrooms. A single exhaust fan is used with an exhaust grille in each bathroom.

A vented kitchen range hood is ducted separately to the exterior and is interlocked with a separate make-up air fan. 


\section{System 2: Forced Air-Outside Air to Return Side of Air Handler, Supplemental Dehumidification}

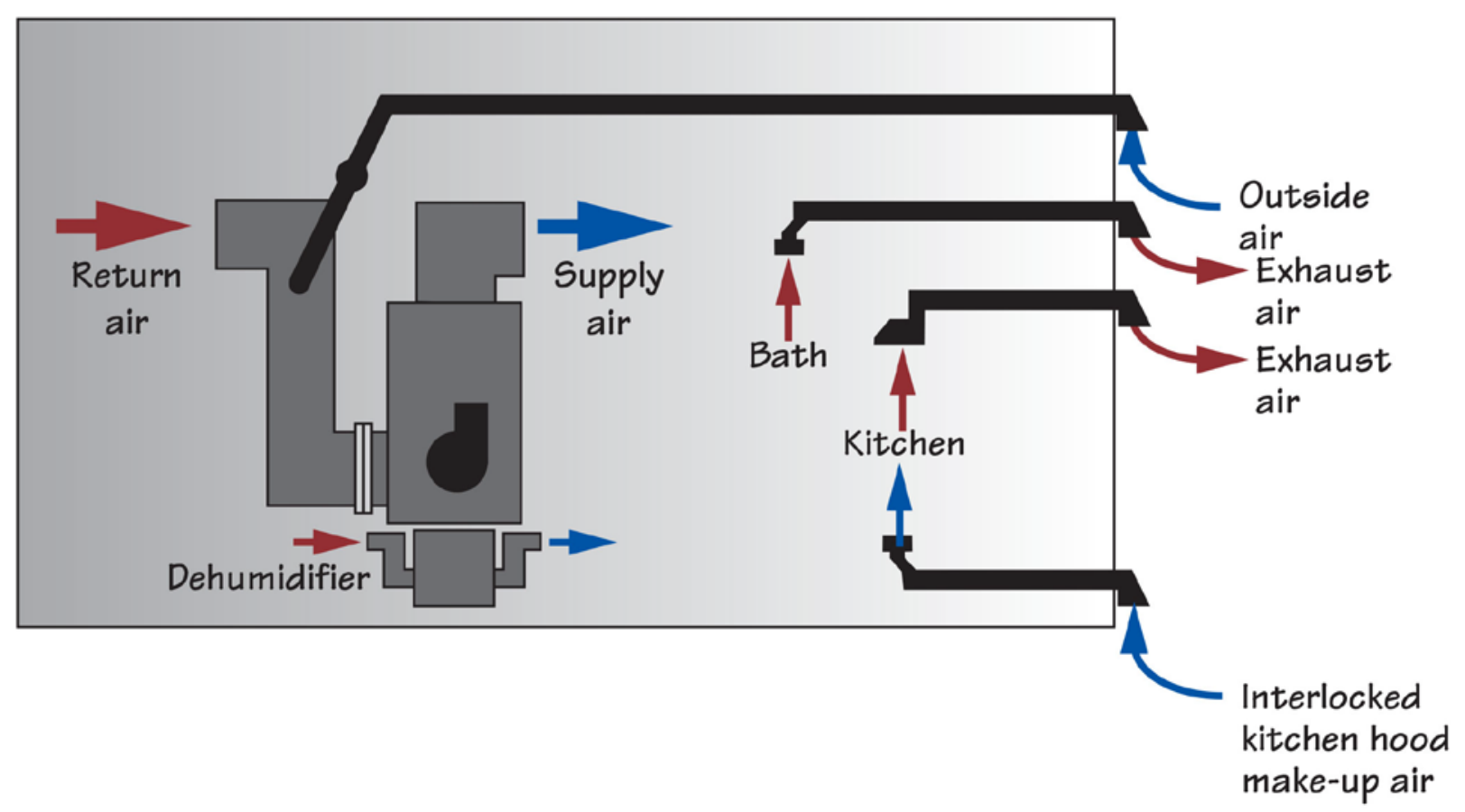

Figure 30. Forced air-Outside air to return to side of air handler, supplemental dehumidification

An outside air duct is connected to the return side of the air handler, and the air handler operates continuously. The air handler is interlocked with a continuous bathroom exhaust fan. The ventilation rate is set according to ASHRAE Standard 62.2. The rate at which outside air is brought in through the outside air duct is matched by the exhaust rate of the bathroom exhaust. For example, if $45 \mathrm{cfm}$ is supplied via the outside air duct, the bathroom fan exhausts continuously at a rate of $45 \mathrm{cfm}$. If two bathrooms are in the unit, the exhaust rate is split between the two bathrooms. A single exhaust fan is used with an exhaust grille in each bathroom.

A vented kitchen range hood is ducted separately to the exterior and is interlocked with a separate make-up air fan.

Supplemental dehumidification is provided by a dehumidifier. 
System 3: Forced Air-Heat Recovery Ventilator/Energy Recovery Ventilator

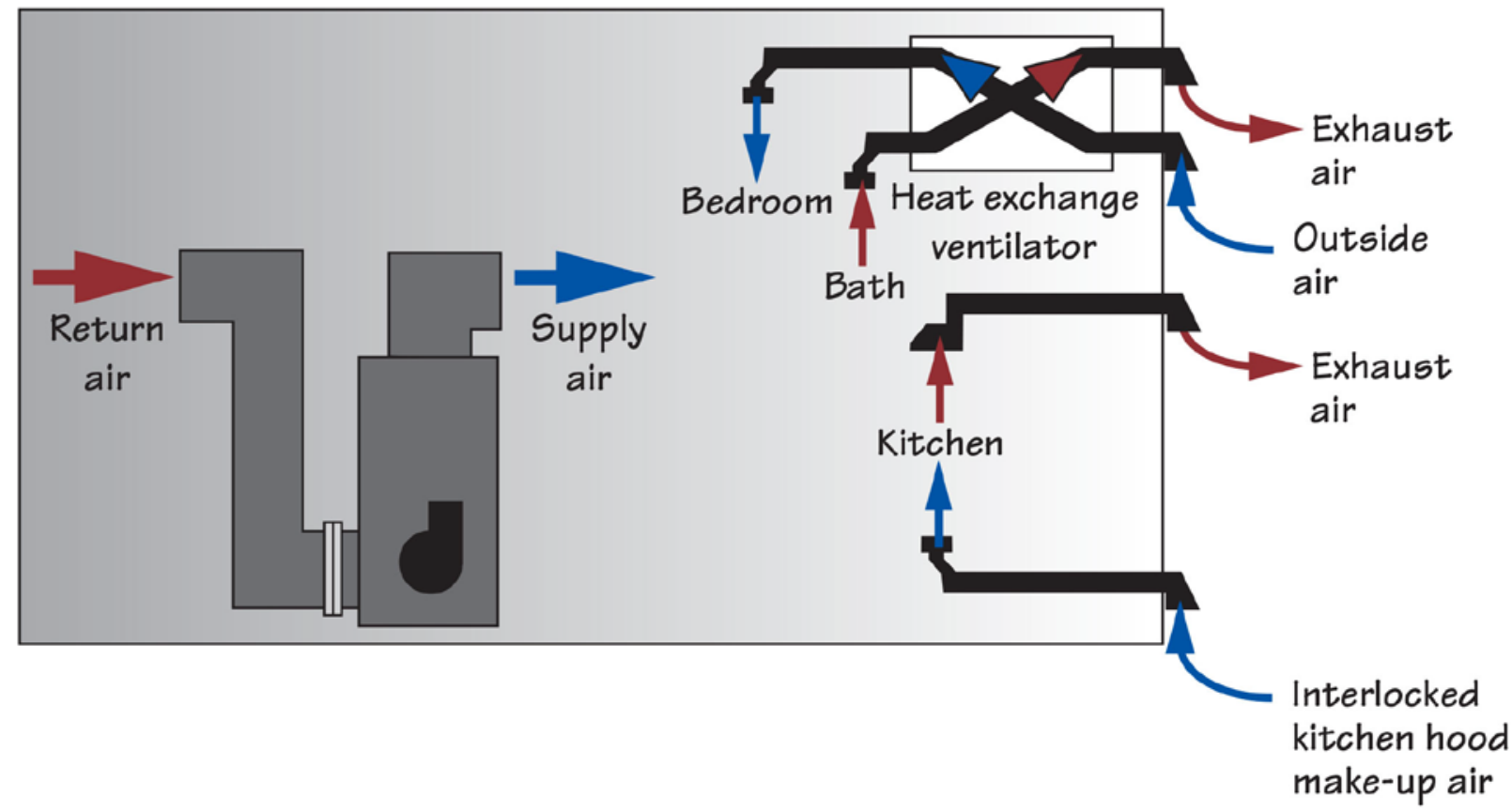

Figure 31. Forced air-Heat recovery ventilator/energy recovery ventilator

A fully ducted HRV or ERV provides balanced ventilation independent of the forced air conditioning system. The HRV/ERV extracts air from the bathroom(s) and supplies air to the bedroom(s).

A vented kitchen range hood is ducted separately to the exterior and is interlocked with a separate make-up air fan. 


\section{System 4: Forced Air-Heat Recovery Ventilator/Energy Recovery Ventilator, Supplemental Dehumidification}

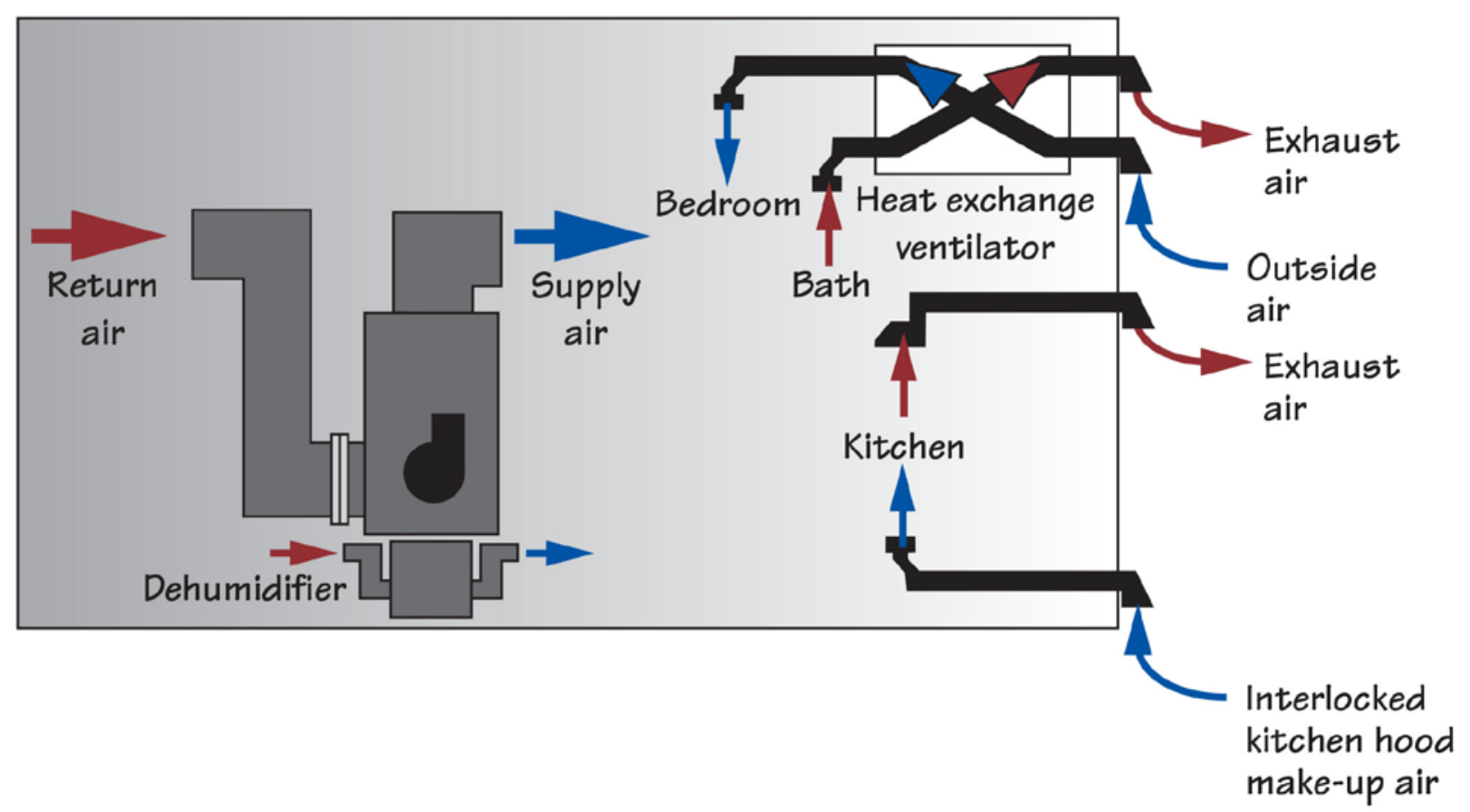

Figure 32. Forced air-Heat recovery ventilator/energy recovery ventilator, supplemental dehumidification

A fully ducted HRV or a fully ducted ERV provides balanced ventilation independent of the forced air conditioning system. The HRV/ERV extracts air from the bathroom(s) and supplies air to the bedroom(s).

A vented kitchen range hood is ducted separately to the exterior and is interlocked with a separate make-up air fan.

Supplemental dehumidification is provided by a dehumidifier. 
System 5: Packaged Terminal Heat Pump-Heat Recovery Ventilator/Energy Recovery Ventilator

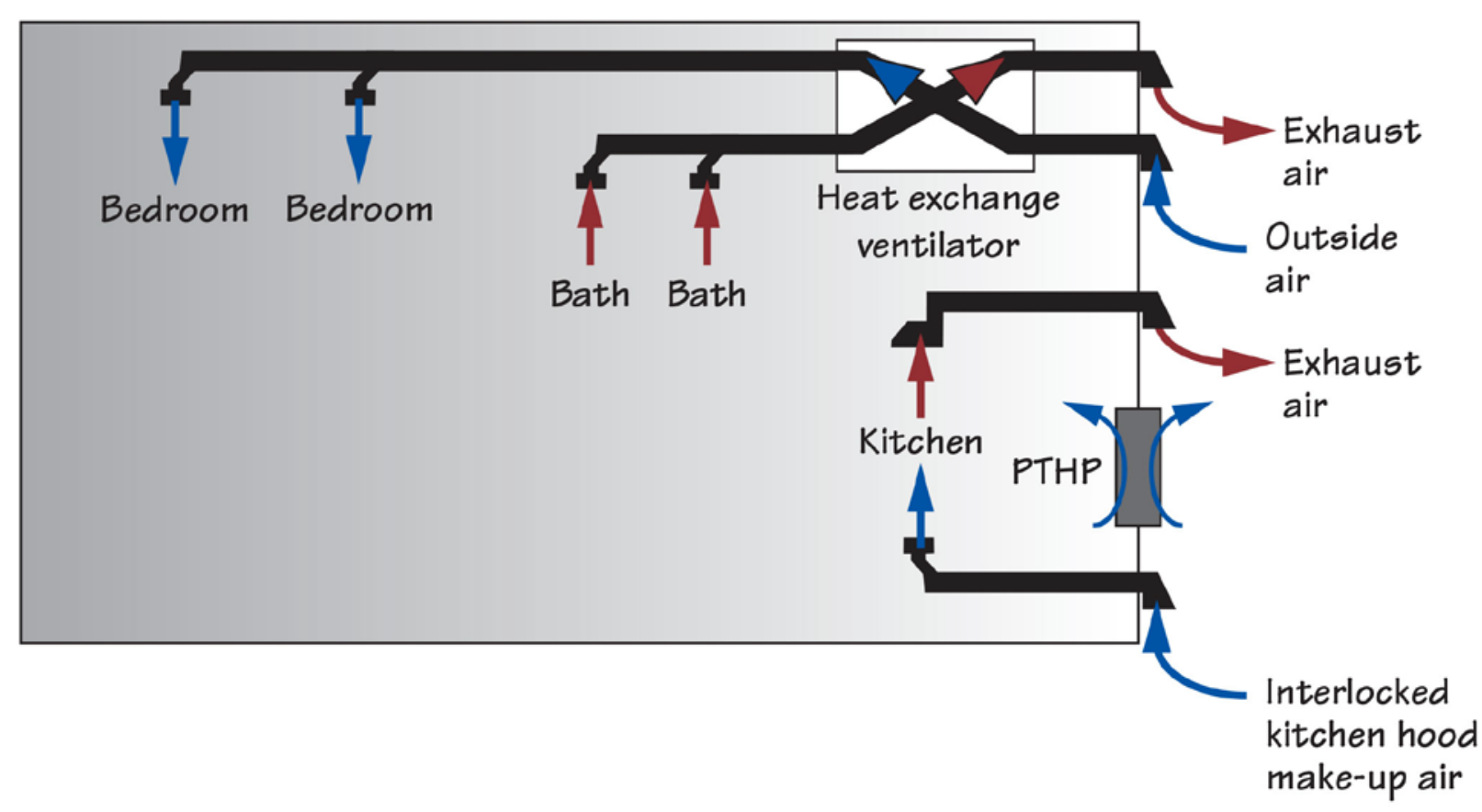

Figure 33. Packaged terminal heat pump-Heat recovery ventilator/energy recovery ventilator

A fully ducted HRV or a fully ducted ERV provides balanced ventilation independent of the PTHP conditioning system. The HRV/ERV extracts air from the bathroom(s) and supplies air to the bedroom(s).

A vented kitchen range hood is ducted separately to the exterior and is interlocked with a separate make-up air fan. 


\section{System 6: Packaged Terminal Heat Pump-Heat Recovery Ventilator/Energy Recovery Ventilator, Supplemental Dehumidification}

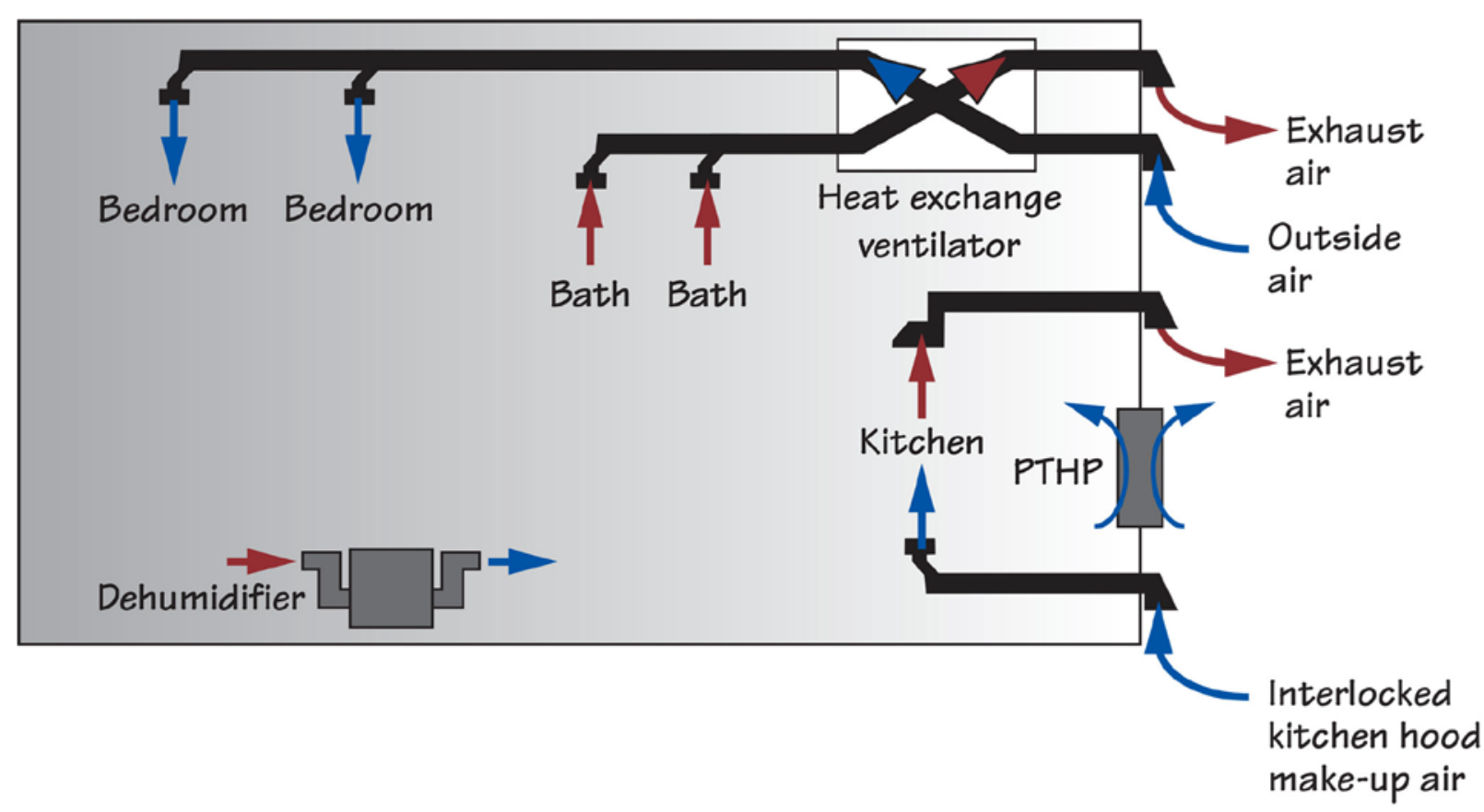

Figure 34. Packaged terminal heat pump-Heat recovery ventilator/energy recovery ventilator, supplemental dehumidification

A fully ducted HRV or a fully ducted ERV provides balanced ventilation independent of the PTHP conditioning system. The HRV/ERV extracts air from the bathroom(s) and supplies air to the bedroom(s).

A vented kitchen range hood is ducted separately to the exterior and is interlocked with a separate make-up air fan.

Supplemental dehumidification is provided by a dehumidifier. 
System 7: Radiant Heating-Heat Recovery Ventilator/Energy Recovery Ventilator

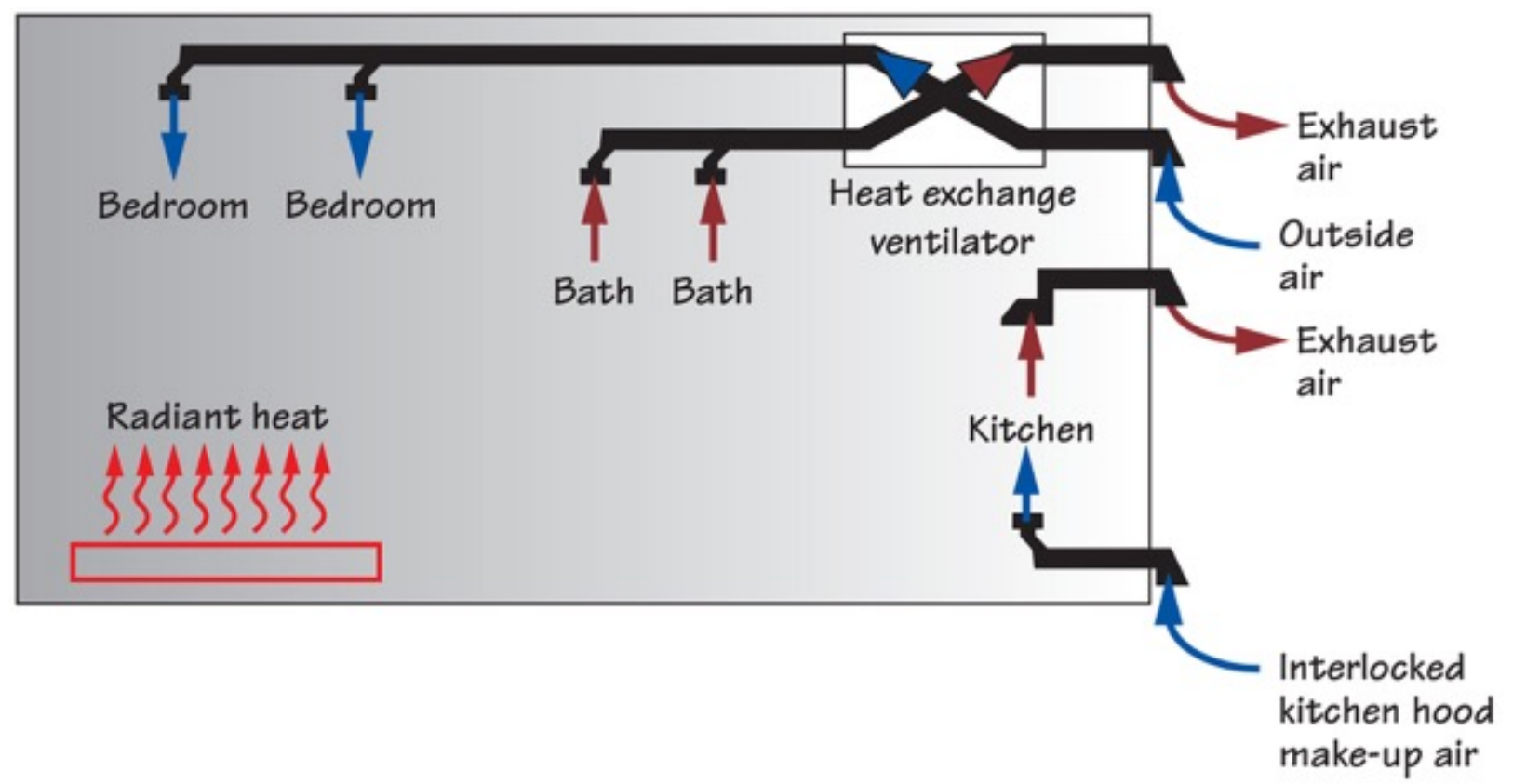

Figure 35. Radiant heating-Heat recovery ventilator/energy recovery ventilator

A fully ducted HRV or a fully ducted ERV provides balanced ventilation. Heating is provided by a radiant heating system. The HRV/ERV extracts air from the bathroom(s) and supplies air to the bedroom(s).

A vented kitchen range hood is ducted separately to the exterior and is interlocked with a separate make-up air fan. 


\section{$5 \quad$ Verification Procedures and Tests}

Ventilation system flow rate should be verified to be compliant with design. Control system operation should be verified. 


\section{References}

[ASHRAE] American Society of Heating, Refrigerating, and Air-Conditioning Engineers, Inc. (2011). 2011 ASHRAE Handbook HVAC Applications. Atlanta, GA: American Society of Heating, Refrigerating and Air-Conditioning Engineers, Inc.

[ASHRAE] American Society of Heating, Refrigerating, and Air-Conditioning Engineers, Inc. (2013). ASHRAE Standard 62.2-2016-Ventilation and Acceptable Indoor Air Quality in LowRise Residential Buildings (ANSI/ASHRAE Approved). Atlanta, GA: American Society of Heating, Refrigerating and Air-Conditioning Engineers, Inc.

[CMHC] Canada Mortgage and Housing Corporation. (2005). "Assessment of Suite Compartmentalization and Depressurization in New High-Rise Residential Buildings." Research Highlight, Technical Series 05-112, October 2005.

Finch, G., Straube, J., and Genge, C. (2009). "Air Leakage Within Multi-Unit Residential Buildings: Testing and Implications for Building Performance." $\left(12^{\text {th }}\right.$ Canadian Conference on Building Science and Technology, Montreal, PQ, October 2009).

Handegord, G.O. (2001). "A New Approach to Ventilation of High Rise Apartments." (Proceedings of the Eighth Conference on Building Science and Technology, Ontario Building Envelope Council, Toronto, Ontario, February 2001).

[ICC] International Code Council. (2015). International Residential Code. Country Club Hills, IL: International Code Council, Inc.

Lstiburek, J.W. (2005). "Multifamily Buildings." ASHRAE Journal, December 2005. Atlanta, GA: American Society of Heating, Refrigeration, and Air-Conditioning Engineers, Inc.

Lstiburek, J.W. (2013). "Unintended Consequences Suck.” ASHRAE Journal, June 2013. Atlanta, GA: American Society of Heating, Refrigeration, and Air-Conditioning Engineers, Inc.

Lstiburek, J.W. (2014). "How Buildings Stack Up." ASHRAE Journal, February 2014. Atlanta, GA: American Society of Heating, Refrigeration, and Air-Conditioning Engineers, Inc.

Maxwell, S., Berger, D., and Zaluga, M. (2014). Evaluation of Ventilation Strategies in New Construction Multifamily Buildings. NREL/SP-KNDJ-0-40342-04. Golden, CO: National Renewable Energy Laboratory; Norwalk, CT: Steven Winter Associates, Inc., Consortium for Advanced Residential Buildings.

Rudd, Armin. (2013). "BA-1310: Supplemental Dehumidification in Warm-Humid Climates." Building Science Corporation. Accessed October 22, 2013. http://www.buildingscience.com/documents/bareports/ba-1310-supplementaldehumidification-warm-humid-climates/view. 
Ueno, Kohta; Lstiburek, Joseph; Bergey, Daniel. (2012). "BA-1209: Multifamily Ventilation Retrofit Strategies.” Building Science Corporation. Accessed October 22,

2013. http://www.buildingscience.com/documents/bareports/ba-1209-multifamily-ventilationretrofit-strategies/view.

U.S. Department of Energy. (2015). "Building America Case Study: Evaluation of Passive Vents in New-Construction Multifamily Buildings, New York, New York.” DOE/GO-102015-4734, October 2015. 


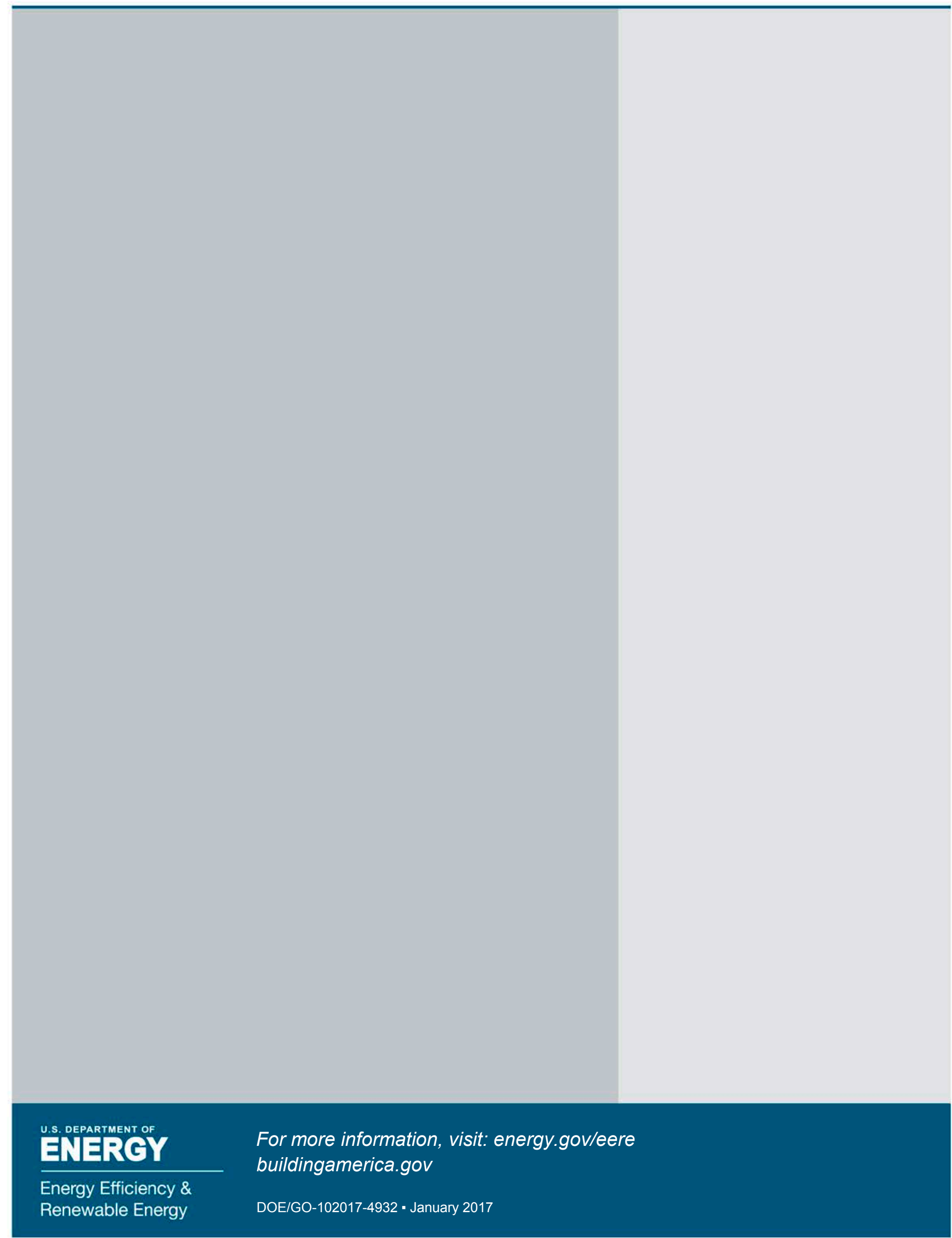

